\title{
A FUNCTIONAL ANALYSIS OF "INDIVIDUAL" AND "INSTITUTIONAL" ACADEMIC FREEDOM UNDER THE FIRST AMENDMENT
}

\author{
David M. RabBan*
}

TABLE of Contents

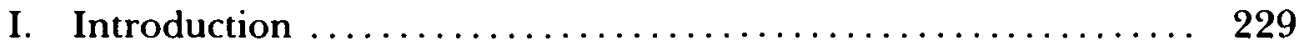

II. The Theory of Academic Freedom in the AAUP's 1915

Declaration ................................. 232

III. Constitutionalizing Academic Freedom ................ 235

IV. A Functional Theory of Constitutional Academic Freedom ..... 241

V. Hints of Judicial Recognition of a Specific Theory of Academic Freedom ........................................

VI. Constitutional Academic Freedom as a Specific Instance of the First Amendment in Institutional Context ............. 246

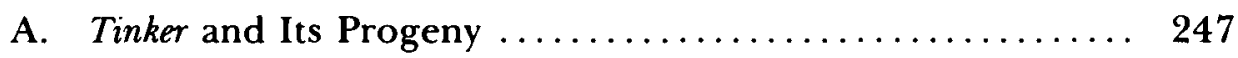

B. Media Cases ............................... 249

C. Institutional Context and the University ............ 252

VII. The Development of Institutional Academic Freedom Under the First Amendment ............................ 256

A. Princeton University v. Schmid ..................... 257

B. University of Pennsylvania v. Equal Employment Opportunity Commission .....................................

Copyright (C) 1990 by Law and Contemporary Problems

* Vinson \& Elkins Professor of Law, The University of Texas School of Law.

I began this article at the College of William and Mary, where I spent the 1989-1990 academic year as the Lee Distinguished Visiting Professor. Charles Koch and Rodney Smolla provided valuable criticisms and suggestions on an early draft. Probing comments and questions from my colleagues during and after a faculty colloquium at the University of Texas School of Law helped enormously as I revised this article. I am grateful to David Anderson, J. Peter Byrne, Matthew Finkin, Steven Goode, Douglas Laycock, Sanford Levinson, William Powers, John Robertson, Jordan Steiker, and Mark Yudof for carefully reading and patiently discussing various drafts. I also thank Amy Gutmann and Walter F. Murphy, professors in the Department of Politics at Princeton University, Thomas M. Scanlon, formerly professor in the Department of Philosophy at Princeton and currently professor of philosophy at Harvard University, and Thomas H. Wright, Princeton's general counsel, for reading and commenting on my treatment of the Schmid case at Princeton.

Much of my thinking about academic freedom derives from fifteen years of stimulating discussions with William Van Alstyne, who was president of the American Association of University Professors ("AAUP") when I joined its staff as associate counsel in 1976. It is a special pleasure to contribute to a symposium on academic freedom edited by the person from whom I have learned most about this subject. 
VIII. The Constitutional Contours of Institutional Academic Freedom 266

A. The Greater Institutional Academic Freedom of Private Universities ............................... 266

B. Does Institutional Academic Freedom Protect State Universities from Other Branches of Government?

IX. The Tension Between Individual and Institutional Academic Freedom

A. Are Judges Competent to Review Academic Freedom Claims By Professors Against Universities? ............ 283

B. Appropriate Judicial Review of Academic Decisions ....... 287

C. Judicial Review of Internal Debates Over Professional Quality .............................. 290

D. The Status of Intramural Speech on University Affairs .... 294

E. Should Procedural and Structural Protections for Faculty Academic Freedom be Included Within the First Amendment? ............................... 297

X. Conclusion ................................... 300 
Page 227: Summer 1990] "Individual" \& "InStitutional" ACademic Freedom 229

\section{INTRODUCTION}

Definitions of academic freedom have developed in response to actual historical circumstances. Threats to professors from university trustees loomed behind the seminal professional definition produced in 1915 by a committee of eminent professors for the first annual meeting of the American Association of University Professors ("AAUP"). Threats to universities from the state, arising out of general concerns during the late 1940s and 1950s about the dangers of communism to American society and institutions, prompted the cases that led the Supreme Court to identify academic freedom as a first amendment right.

Both the professional and the constitutional definitions of academic freedom ${ }^{\prime}$ stressed the value of critical inquiry in universities. But each definition understandably focused on the distinctive contemporary threats to this value. Not surprisingly, the AAUP definition, which was eventually accepted by many universities and educational organizations, emphasized the protection of individual professors against lay trustees, whereas the constitutional definition emphasized the protection of the entire university community against state intervention. Neither definition, however, was monolithic. The AAUP recognized the danger to academic inquiry from legislative interference, and Supreme Court opinions treated constitutional academic freedom as an individual right of professors as well as an institutional right of universities.

For many years, "individual" and "institutional" definitions of academic freedom seemed complementary rather than in tension with each other. Significantly, the AAUP's first Supreme Court brief on the subject of academic freedom stressed that university autonomy from the state is a necessary condition for the academic freedom of professors. ${ }^{2}$ Yet the dramatic growth of litigation by students and professors against universities, dating roughly from the late 1960s, has highlighted the tension between individual and institutional academic freedom. Increasingly, administrators and trustees have invoked institutional academic freedom not as an additional layer of protection for professors against the state, but as a bar to judicial review of claims against universities by professors alleging institutional violations of individual academic freedom.

1. Walter P. Metzger, Profession and Constitution: Two Definitions of Academic Freedom in America, 66 Tex L Rev 1265 (1988), is the work that most explicitly identifies and compares the professional and constitutional definitions. I find these two definitions much more compatible than does Professor Metzger. See, for example, text accompanying notes 4-5, 44-46, 50-57, 254-58. See also J. Peter Byrne, Academic Freedom: A "Special Concern of the First Amendment," 99 Yale L J 251 (1989) (following Metzger in contrasting individual emphasis of professional definition with institutional emphasis of constitutional definition); David M. Rabban, Academic Freedom, in Leonard Levy, Kenneth L. Karst \& Dennis J. Mahoney, eds, I Encyclopedia of the American Constitution 12 (MacMillan, 1986) (comparing uncertainty of constitutional definition with elaborated professional definition).

2. AAUP's Brief as Amicus Curiae, Barenblatt v United States, 360 US 109 (1959). 
Unfortunately, the Supreme Court's glorification of academic freedom as a "special concern of the First Amendment"3 has produced hyperbolic rhetoric but only scant, and often ambiguous, analytic content. The Court has never explained systematically the theory behind its relatively recent incorporation of academic freedom into the first amendment, a problem occasionally acknowledged by the justices themselves. Without such a theory, it is difficult to address the constitutional implications of the tension between the individual and institutional components of academic freedom.

Some commentators have maintained that the courts, especially the Supreme Court, seem to be defining constitutional academic freedom exclusively in institutional terms. ${ }^{4}$ Indeed, a major recent analysis comments approvingly on this perceived development. ${ }^{5}$ I disagree. Courts may have been presented with more institutional claims than individual claims of academic freedom, but they have also recognized that the first amendment protects individual academic freedom. Although courts have identified both forms of academic freedom, they have not fully addressed, and certainly have not resolved, the tensions between them.

In this article, I summarize and contrast the professional and constitutional treatments of academic freedom, justify distinctive first amendment analysis of academic speech that differs both from the professional definition of academic freedom and from the constitutional free speech of citizens generally, and respond to arguments that courts lack competence to decide academic freedom disputes between professors and universities. In my opinion, academic freedom is more than just a desirable policy promoted by the AAUP and adopted within the academic world. Core first amendment values-such as critical inquiry, the search for knowledge, and toleration of dissent-support constitutionalizing some, but not all, of the speech covered by the professional definition of academic freedom. These first amendment values justify protecting both the professional speech of faculty and the autonomy of universities to make decisions about educational policy. In order to engage in critical inquiry, professors need some degree of independence from their university employers, and universities need some degree of independence from the state. Asserting constitutional protection for professors and universities is not simply a form of special pleading to elevate the job-related concerns of a particular profession or the institutional interests of a particular enterprise. Rather, constitutional academic freedom promotes first amendment values of general concern to all citizens in a democracy.

This functional justification of academic freedom as "a special concern of the First Amendment" is theoretically defensible as applied only to the distinctive roles of professors and universities. Yet first amendment academic freedom can be viewed doctrinally as an aspect of a developing but

3. Keyishian v Board of Regents, 385 US 589, 603 (1967).

4. See Byrne, 99 Yale L J 251 (cited in note 1); Metzger, 66 Tex L Rev 1265 (cited in note 1).

5. Byrne, 99 Yale L J 251 (cited in note 1). 
insufficiently appreciated judicial trend to construe the first amendment in institutional context. Universities are not the only institutions to which special first amendment rules apply. Courts have increasingly observed that the level of first amendment protection varies with the functions of institutions. Newspapers and libraries, for example, are subject to very different first amendment standards than military bases and prisons. Similarly, the Supreme Court has frequently distinguished institutional functions in explaining why more restrictions on speech are appropriate in elementary and secondary schools than in universities. In a meaningful sense, first amendment academic freedom is only an illustration of the general first amendment principle that special rules about speech must be tailored to the distinctive functions of various institutions. First amendment academic freedom is "special," but so are the free speech rules that apply in other institutions with different functions. These other free speech rules may not have been separately named, as the Supreme Court has specifically extolled "academic freedom," but they serve the similar purpose of applying the first amendment in institutional context.

After attempting to justify the Supreme Court's constitutionalization of academic freedom, I address the complicated circumstances in which first amendment academic freedom claims may arise and potentially conflict. Three basic categories stand out: claims of professors against faculty colleagues, administrators, or trustees; claims of professors against the state; and claims of universities against the state. The state action necessary to invoke the first amendment exists in all three categories of claims at public universities. In private universities, by contrast, state action applies only to claims by professors and universities against the state. Claims by professors at private institutions against faculty colleagues, administrators, or trustees cannot raise first amendment issues because no state action exists. Yet a private university can assert institutional academic freedom as a defense to judicial review of faculty claims that the university violated its contractual commitments to academic freedom. The state action requirement, in addition to complicating constitutional analysis, illustrates one major difference between the constitutional definition of academic freedom and the professional one, which applies equally in public and private universities.

Constitutional analysis is further complicated because public universities may invoke the first amendment to assert independence from the states that create them, and simultaneously are themselves state institutions constrained by the first amendment. For example, state universities may be subject to some legislative controls from which private universities are constitutionally protected. Yet the first amendment might also require state universities to allow more diversity of thought than private universities. Although I address these important issues, I focus on competing first amendment academic freedom claims between individual professors and state universities, which provide the context of most current disputes. I analyze claims by professors that university decisions justified on academic grounds in fact violate 
academic freedom. Some of these claims allege that the justifications are pretexts, while others allege that the stated grounds themselves reflect impermissible intellectual orthodoxies inconsistent with academic freedom. I conclude by considering attempts to extend individual academic freedom beyond teaching and scholarship to speech on university affairs generally and to faculty participation in university governance.

\section{II}

\section{The Theory of Academic Freedom in the AAUP's 1915 DEclaration}

The AAUP's 1915 Declaration of Principles, ${ }^{6}$ the first comprehensive analysis of academic freedom in the United States, remains the foundation for the nonlegal understanding of academic freedom within the academic world. Adapting the German concept of academic freedom to the American context, the 1915 Declaration limited itself to the academic freedom of the professor, while recognizing that student academic freedom had been a major component of the German tradition. The 1915 Declaration identified three elements of academic freedom: "freedom of inquiry and research; freedom of teaching within the university or college; and freedom of extramural utterance and action." The authors explained their inclusion of extramural freedom, which had not been part of the German understanding of faculty academic freedom, by observing that this issue had arisen more frequently than the other two in the five investigations of university controversies already completed by AAUP committees during the year since the association's founding. ${ }^{7}$

The 1915 Declaration defined academic freedom in relation to the functions of professors and universities. It viewed the basic role of professors as sharing the results of their independent and expert scholarly investigations with students and the general public. ${ }^{8}$ Academic freedom, it added, serves the fundamental purposes of universities, identified as promoting inquiry and knowledge, providing instruction to students, and, reflecting a key theme of the progressive era, developing experts for public service. ${ }^{9}$ Throughout this discussion, the 1915 Declaration stressed the social benefits of scholarly work in universities. Education and knowledge, it reiterated, are essential to a civilized and democratic society. ${ }^{10}$ In florid but deeply felt language, the 1915

6. AAUP, Declaration of Principles (1915), reprinted in Louis Joughin, ed, Academic Freedom and Tenure, app A at 157-76 (Univ of Wisconsin Press, 1969) (“1915 Declaration”); see Appendix A, 53 L. \& Contemp Probs 393 (Summer 1990) ("Appendix A").

7. 1915 Declaration at 157-58; Appendix A at 393 (cited in note 6). Metzger, 66 Tex L Rev at 1275 (cited in note 1), rather than the 1915 Declaration itself, highlights the inclusion of extramural freedom as an addition to the German model. See also Walter P. Metzger, The German Contribution to the American Theory of Academic Freedom, in Walter P. Metzger, ed, The American Concept of Academic Freedom (Arno Press, 1977).

8. 1915 Declaration at 162; Appendix $A$ at 396 (cited in note 6).

9. 1915 Declaration at 163-64; Appendix $A$ at 397, 398 (cited in note 6).

10. 1915 Declaration at 161, 163, 166-68; Appendix A at 396, $397-99$ (cited in note 6). 
Declaration emphasized that the university "should be an intellectual experiment station, where new ideas may germinate and where their fruit, though still distasteful to the community as a whole, may be allowed to ripen until finally, perchance, it may become a part of the accepted intellectual food of the nation or of the world." Yet the 1915 Declaration simultaneously cautioned that the university also makes a social contribution by conserving unfashionable but valuable intellectual traditions and by checking both the hasty impulses of popular opinion and the tendency toward conformity in modern democracies. ${ }^{11}$

The 1915 Declaration identified threats to academic freedom as impediments to these functions. It focused primarily on boards of trustees, the acknowledged source of power in universities. ${ }^{12}$ Unfortunately, trustees, who should view themselves as holders of a public trust in private as well as in public institutions, too often acted as if they were simply autocratic employers. Many trustees felt free to use the power of dismissal to impose their personal ideological and pedagogical views on professors. Such a conception of the university as the equivalent of "an ordinary business venture," the 1915 Declaration protested, reveals "a radical failure to apprehend the nature of the social function discharged by the professional scholar." 13 Professorial opinions lose their value if any suspicion exists that they are not the product of free scholarly inquiry but are guided by the untrained and self-interested views of others. Professors, like judges, should be regarded as appointees rather than as employees, because both professors and judges must remain independent of their nominal employers in order to perform their professional functions. It is as inappropriate for trustees to dictate conclusions to a professor as it is for the president to dictate legal reasoning to the judges he appoints. Correspondingly, neither trustees nor presidents are responsible for the opinions their appointees express. ${ }^{14}$

Although the 1915 Declaration focused on trustees, it also identified the threat posed by legislatures to academic freedom in state universities. Observing the dependence of state universities on legislative funding, the 1915 Declaration worried that legislators might try to use the state's purse strings to manipulate the academic inquiries of professors, particularly when scholarly views might deviate from strong public opinions or from established government policies. While trustee interference with academic freedom would typically derive from the opposition of businessmen to the more liberal social and economic views of professors, ${ }^{15}$ state and public pressure would

11. 1915 Declaration at 167-68; Appendix $A$ at 400 (cited in note 6).

12. Metzger, 66 Tex L Rev at 1276-78 (cited in note 1) makes clear that the drafters of the 1915 Declaration decided not to challenge lay legal control of universities. Convinced about the certain failure of any such challenge, they accepted that " "outside' was ensconsed within." Id at 1277.

13. 1915 Declaration at 161; Appendix $A$ at 396 (cited in note 6).

14. See generally 1915 Declaration at 160-63; Appendix $A$ at 397 (cited in note 6).

15. The 1915 Declaration observed that ecclesiastical interference with philosophy and the natural sciences constituted the main threat to academic freedom in earlier periods of American history. 1915 Declaration at 165-66; Appendix A at 399-400 (cited in note 6). 
predictably threaten conservative professors who disagree with a political program of reform. Whatever the ideological source of these pressures on academic freedom, the 1915 Declaration emphasized, the university should be an "inviolable refuge" for independent scholarly investigation. ${ }^{16}$

The committee of professors who drafted the 1915 Declaration made a special point of dissociating academic freedom from broad claims of faculty autonomy. "It is," they maintained, "in no sense the contention of this committee that academic freedom implies that individual teachers should be exempt from all restraints as to the matter or manner of their utterances, either within or without the university."17 Professors who fail to meet scholarly standards of competence, or who abuse their positions to indoctrinate students, cannot claim the protection of academic freedom and can be disciplined. ${ }^{18}$ Yet while lay governing boards are competent to evaluate disputes over morals or neglect of duties, controversies involving the expression of scholarly opinion must be judged, at least initially, by professional peers, who alone have the necessary qualifications. Assigning this responsibility to others inevitably raises the suspicion of a decision based on irrelevant and improper motives. ${ }^{19}$

After substantial internal debate, the drafters of the 1915 Declaration decided that the academic freedom they were extending to extramural utterances should not be limited to subjects within a scholar's professional specialties. Some expressed concern that broad protection for extramural utterances would encourage professors to speak irresponsibly beyond their expertise and would unjustifiably give them more rights to political expression than other employees. The view that ultimately prevailed acknowledged the "obvious" point that professors speaking outside the university "are under a peculiar obligation to avoid hasty or unverified or exaggerated statements, and to refrain from intemperate or sensational modes of expression." But the 1915 Declaration also quoted with approval the conclusion of a Wisconsin state agency that "it is neither possible nor desirable to deprive a college professor of the political rights vouchsafed to every citizen."'20

In context, this quotation was seriously misleading. Existing law made clear that both public and private employees could be fired by employers for speech the employees were free to make as citizens. In Holmes's famous phrase, "petitioner may have a constitutional right to talk politics, but he has no constitutional right to be a policeman."21 Holmes could have made the

16. 1915 Declaration at 167-68; Appendix A at 400 (cited in note 6).

17. 1915 Declaration at 173; Appendix A at 404 (cited in note 6).

18. See 1915 Declaration at 170,173 ; Appendix $A$ at 402,404 (cited in note 6).

19. 1915 Declaration at 173-74; Appendix A at 404-05 (cited in note 6); see David M. Rabban, Does Academic Freedom Limit Faculty Autonomy?, 66 Tex L Rev 1405, 1408-12 (1988) (discussing limits on faculty autonomy in 1915 Declaration's conception of academic freedom).

20. 1915 Declaration at 172; Appendix A at 404 (cited in note 6). The 1915 Declaration left open to future consideration whether professors should take prominent roles in political parties or run for public office. Id.

21. McAuliffe v Mayor of New Bedford, 155 Mass 216, 220, 29 NE 517, 518 (1892). 
same statement had the petitioner been a university professor. Perhaps for this reason, and because professors actually were being dismissed for extramural speech unrelated to teaching or research, the 1915 Declaration "stretched the cloak of protection over an area in which academics proved to be most exposed."'22

The 1915 Declaration conceded that some universities were endowed expressly to propagate certain doctrines, citing as examples universities sponsored by religious denominations, a school established by a manufacturer to advocate a protective tariff, and an institution funded to advance socialism. The 1915 Declaration explicitly refused to comment about whether such "proprietary institutions" should exist, though it did observe that they were becoming increasingly rare. Rather, it emphasized that they "should not be permitted to sail under false colors." Proprietary institutions, which are devoted to the inculcation of ideas, must be distinguished from "ordinary institutions of learning," which are committed to critical inquiry. Any university that denies academic freedom to its faculty, the 1915 Declaration insisted, is a proprietary institution that does not perform the functions of a true university and thus does not merit public support. ${ }^{23}$

\section{III}

\section{Constitutionalizing Academic Freedom}

The term "academic freedom" first attracted constitutional attention during the 1950s, in connection with the more general response by the Supreme Court to government investigations of alleged communist conspiracies. ${ }^{24}$ Yet even Supreme Court decisions that mentioned academic

22. Metzger, 66 Tex L Rev at 1276 (cited in note 1). Although Professor Arthur Lovejoy played a crucial role in convincing his collaborators on the 1915 Declaration to take this position, he subsequently defined academic freedom as limited to teaching and research. Arthur $O$. Lovejoy, Academic Freedom, in Edwin R. A. Seligman, ed, 1 Encyclopedia of the Social Sciences 384 (MacMillan, 1930). See Metzger, 66 Tex L Rev at $1275 \mathrm{n} 23,1276$ (cited in note 1). William W. Van Alstyne, The Specific Theory of Academic Freedom and the General Issue of Civil Liberly, in Edmund L. Pincoffs, ed, The Concept of Academic Freedom 59, 61-63 (University of Texas Press, 1972) ("The Specific Theory of Academic Freedom"), criticizes the extension of academic freedom in the 1915 Declaration to include "aprofessional political liberties."

23. 1915 Declaration at 158-60; Appendix A at 394-95 (cited in note 6). In contrast to the usage of the 1915 Declaration, "proprietary" normally refers to institutions that are organized for profit. See Marjorie Webster Jr. College v Middle States.Ass'n of Colleges and Secondary Schools, Inc., 432 F2d 650 (DC Cir 1970) (challenge by proprietary junior college to policy limiting accreditation to nonprofit institutions).

24. Prior Supreme Court decisions, without referring to the first amendment or to academic freedom, protected both teachers and educational institutions from state interference. Chief Justice Marshall's famous opinion in the Dartmouth College case was an early example. Trustees of Dartmouth College $v$ Woodward, 17 US (4 Wheat) 518, 652 (1819) (relying on impairment of contracts clause of U.S. Constitution to uphold "will of the donors" against "will of the state"). Several decisions in the 1920 s relied on the due process clause of the 14th amendment to invalidate state laws regulating education. See, for example, Farrington $v$ Tokushige, 273 US 284 (1927) (invalidating state regulation of instruction and curriculum in foreign language schools); Pierce $v$ Society of Sisters, 268 US 510 (1925) (invalidating state law compelling public school attendance); Meyer $v$ Nebraska, 262 US 390 (1923) (invalidating state law prohibiting instruction in foreign language before eighth grade). Many scholars have emphasized that these decisions constitutionally safeguarded institutional autonomy and pluralism. See, for example, Mark G. Yudof, When Government Speaks: Politics, Law, and Government 
freedom did not focus on its meaning. The holdings in those cases were based on traditional constitutional doctrines involving political expression, ${ }^{25}$ due process, ${ }^{26}$ and the privilege against self-incrimination. ${ }^{27}$ The few opinions that invoked academic freedom did so more for rhetorical effect than as an aid to constitutional analysis. Some of these opinions, however, identified academic freedom as a distinctive right within the first amendment and applied the concept to both individuals and institutions. For example, in Sweezy v. New Hampshire, the Supreme Court decision that initially incorporated academic freedom within the first amendment, the plurality opinion referred to a lecturer's personal "liberties in the areas of academic freedom and political expression" and added that " $[t]$ he essentiality of freedom in the community of American universities is almost self-evident.",28

The relationship between the theory of academic freedom elaborated in the 1915 Declaration and the new constitutional right of academic freedom under the first amendment remains unclear. ${ }^{29}$ Courts have used academic freedom and free speech interchangeably or ambiguously, have attached

Expression in America 227-30 (Univ of Cal Press, 1983); Matthew W. Finkin, On "Institutional" Academic Freedom, 61 Tex L Rev 817, 830-40 (1983); Stephen R. Goldstein, The Asserted Constitutional Right of Public School Teachers to Determine What They Teach, 124 U Pa L Rev 1293, 1305-09 (1976); William W. Van Alstyne, Academic Freedom and the First Amendment in the Supreme Court of the United States: An Unhurried Historical Review, 53 L \& Contemp Probs 79, 88-93 (Summer 1990); Mark G. Yudof, Three Faces of Academic Freedom, 32 Loyola L Rev 831, 852-53 (1987).

25. See, for example, Barenblatt v United States, 360 US 109 (1959); Sweezy v New Hampshire, 354 US 234 (1957); Adler v Board of Educ., 342 US 485 (1952).

26. See, for example, Wieman v Updegraff, 344 US 183 (1952).

27. See, for example, Slochower $v$ Board of Educ., 350 US 551 (1956). The treatment in constitutional law casebooks of the early Supreme Court decisions mentioning academic freedom reinforces the perception that these cases were primarily about other issues. See, for example, Paul Brest \& Sanford Levinson, Processes of Constitutional Decisionmaking 1102-09 (Little Brown, 2d ed 1983) (treating Barenblatt under heading "Can the state require speech or expression from an unwilling citizen?"); Gerald Gunther, Constitutional Law 1406-10 (Foundation Press, 11 th ed 1985) (treating Sweezy and Barenblatt under heading "legislative investigations"), 1364-66 (treating Wieman and Slochower under heading "government demands for information and affirmation"); William Lockhart, et al, Constitutional Law 983-87 (West, 6th ed 1986) (treating Barenblatt under heading "government mandated disclosures and freedom of association"); Geoffrey R. Stone, et al, Constitutional Law 131618 (Little Brown, 1986) (treating Sweezy and Barenblatt under heading "legislative investigations"), 1288 (treating Adler and Wieman under heading "subversive advocacy and association").

In his comprehensive treatise, Professor Tribe does not have a separate section on academic freedom. Rather, he discusses academic freedom in a lengthy footnote in a section entitled "distinguishing government's addition of its own voice from government's silencing of others." Laurence Tribe, American Constitutional Law 812-13 n32 (Foundation Press, 2d ed 1988).

28. Sweezy, 354 US at 250. See Rabban, Academic Freedom at 13 (cited in note 1).

Professors interested in academic freedom immediately recognized the importance of Sweezy. "To the members of the academic profession," wrote a professor at Dartmouth College who had served as general secretary of the AAUP,

Sweezy $v$ New Hampshire is quite possibly the most significant decision ever rendered by the Supreme Court. Here for the first time in history a majority of the Court indicates its conviction that academic freedom is protected by the First and Fourteenth Amendments of the Constitution against encroachment by either the federal or state governments.

Robert K. Carr, Academic Freedom, the American Association of University Professors, and the United States Supreme Court, 45 AAUP Bull 5, 17 (1959).

29. Byrne, 99 Yale L J 251 (cited in note 1), presents the fullest discussion of the relationship between the AAUP definition and the constitutional definition of academic freedom. Metzger, 66 Tex L Rev 1265 (cited in note 1), provides an excellent taxonomy of these two definitions while emphasizing how they differ rather than how they relate. See especially id at 1267 . 
academic freedom to professors as well as to universities, and have extended it to teachers in public schools and to students generally without considering how its meaning might differ in these various contexts. ${ }^{30}$ In my opinion, a convincing justification for constitutional academic freedom requires a thorough comparison of general first amendment theories with nonlegal theories of academic freedom, yielding conclusions about where these various theories do and do not overlap. ${ }^{31}$ I do not attempt such an ambitious task here. But some conception of constitutional academic freedom is necessary to analyze the relationship between the individual academic freedom of the professor and the institutional academic freedom of the university, which is the primary concern of this article. I therefore do consider reasons for protecting academic freedom under the first amendment.

Fitting academic freedom within the rubric of the first amendment is in many respects an extremely difficult challenge. The term "academic freedom," in obvious contrast to "freedom of the press," is nowhere mentioned in the text of the first amendment. It is inconceivable that those who debated and ratified the first amendment thought about academic freedom. Indeed, before the Civil War, when most institutions of higher education were denominational colleges, "the problem of academic freedom as we now understand it was hardly posed"32 even as a nonlegal matter. These colleges were what the subsequent 1915 Declaration labeled "proprietary," concerned with conserving truth rather than with searching for it. They did not allow intellectual freedom, and their faculties typically did not seek it. Notions of academic freedom, to the extent they existed at all, were associated with institutional autonomy from the democratic vulgarity of the broader society. Only with the emergence of the modern research university in the late nineteenth century did a comprehensive theory of academic freedom, expressed most thoroughly in the 1915 Declaration, emerge in the United States. It took an "educational revolution"33 following the Civil War to produce the commitment to critical inquiry central to the modern rationale for academic freedom, ${ }^{\mathbf{3 4}}$ and arguably related to general free speech theories contained within the first amendment. "It may put some of our current difficulties into perspective," wrote the authors of the leading history of American academic freedom just before the Supreme Court gave the term constitutional meaning, "that the academic freedom which is now

30. See Metzger, 66 Tex L Rev at 1291-1322 (cited in note 1); Rabban, Academic Freedom at 12 (cited in note 1). Professor Metzger offers a particularly thorough analysis of the many contexts in which the Supreme Court has considered academic freedom claims. In my opinion, he provides a more coherent synthesis and rationale for the Court's decisions addressing academic freedom and free speech at schools and universities than the justices themselves intended or than the cases allow.

31. One obvious difference between the professional and constitutional definitions of academic freedom is that the first amendment, through its incorporation in the 14 th amendment, applies only to state action. The professional definition of academic freedom, by contrast, has no state action requirement.

32. Richard Hofstadter \& Walter P. Metzger, Preface, v, to Walter P. Metzger, Academic Freedom in the Age of the University (Columbia, 1961) ("Age of the University").

33. Id at vi.

34. Id at v-vi; Metzger, Age of the University at 42-44 (cited in note 32). 
under fire is not an ancient prerogative but an acquisition of relatively recent date."35

A constitutional theory of academic freedom, moreover, understandably implies to many a special first amendment right unique to professors and universities. The free speech guaranteed by the first amendment is generally thought to apply equally to all citizens. ${ }^{36}$ Indeed, even the specific protection for the press provided in a separate clause of the first amendment has been read as providing no greater rights to publishers and journalists than the free speech clause guarantees other citizens. ${ }^{37}$ In these historical and legal circumstances, it would not have been surprising had the Supreme Court refused to recognize a discrete though unenumerated first amendment right of academic freedom. Even those who defend the extension of first amendment protection to academic freedom would have had difficulty criticizing the Court had it declined to do so.

The AAUP itself, based on more pragmatic concerns, was divided about whether to seek constitutional protection for academic freedom. It decided not to submit an amicus brief in Sweezy, in part because it reasonably concluded that the Court was unlikely to address the constitutional implications of academic freedom for the first time, ${ }^{38}$ but also because it worried about judicial appropriation of a concept the AAUP had largely defined and successfully advocated throughout the academic world. Even a favorable definition of academic freedom under the first amendment would be subject to further judicial interpretation. What the Court gave, many within the AAUP worried, it could also take away. Relatedly, constitutional recognition of academic freedom could prompt many within the university community to abandon any continuing independent effort to define and refine this crucial concept. The constitutional meaning of academic freedom could displace rather than complement the one set forth in the 1915 Declaration and accepted in the institutional regulations of many universities. Principles of academic freedom not incorporated into the first amendment could thereby be abandoned entirely. For these reasons, many within the AAUP feared that academic freedom would be weakened through judicial constitutionalization. 39

By identifying academic freedom as a first amendment right, the Supreme Court in Sweezy rendered moot the AAUP's reservations about whether to argue for this position. Subsequent decisions, including one that denied a professor's first amendment claim, ${ }^{40}$ have reinforced the incorporation of

35. Hofstadter \& Metzger, Preface at vi (cited in note 32).

36. See generally Kenneth L. Karst, Equality as a Central Principle in the First Amendment, $43 \mathrm{U}$ Chi L Rev 20 (1975).

37. See text accompanying notes 93-97.

38. Dissenting in a previous case, Justice Douglas objected that a New York law would "raise havoc with academic freedom," but he did not suggest that academic freedom had constitutional dimensions. Adler $v$ Board of Educ, 342 US 485, 509 (1952) (Douglas dissenting).

39. Carr, 45 AAUP Bull at 5, 6, 19-20 (cited in note 28).

40. Barenblatt, 360 US at 112 . 
academic freedom into the first amendment, mostly through additional rhetorical flourishes. Yet some language in Supreme Court decisions suggests the reasoning behind this incorporation, often using terms that echo the 1915 Declaration and indicate close parallels between the justification for academic freedom in the 1915 Declaration and basic themes of general first amendment theory.

One paragraph of Chief Justice Warren's plurality opinion in Sweezy contains the Court's fullest discussion of academic freedom.

The essentiality of freedom in the community of American universities is almost selfevident. No one should underestimate the vital role in a democracy that is played by those who guide and train our youth. To impose any strait jacket upon the intellectual leaders in our colleges and universities would imperil the future of our Nation. No field of education is so thoroughly comprehended by man that new discoveries cannot yet be made. Particularly is that true in the social sciences, where few, if any, principles are accepted as absolutes. Scholarship cannot flourish in an atmosphere of suspicion and distrust. Teachers and students must always remain free to inquire, to study and to evaluate, to gain new maturity and understanding; otherwise our civilization will stagnate and die. ${ }^{41}$

This crucial paragraph, though not very helpful in clarifying the relationship between the new constitutional analysis of academic freedom and its traditional meaning within the university community, does seem to identify two distinct social benefits of academic freedom. Critical inquiry within universities is essential to the preservation of a democratic society and, as a somewhat independent matter, promotes discoveries and understanding necessary for civilization. Justice Frankfurter's famous concurring opinion in Sweezy reiterated both themes. Frankfurter invoked democratic values by stressing "the dependence of a free society on free universities," 42 but focused primarily on knowledge and understanding in the full range of academic disciplines as social goods in themselves. Any "government intrusion into the intellectual life of a university," Frankfurter twice warned, ${ }^{43}$ would jeopardize these essential functions of professors in universities.

The Court's next significant discussion of academic freedom under the first amendment, a decade later in Keyishian $v$. Board of Regents, quoted the key paragraph from the plurality opinion in Sweezy while emphasizing that academic freedom is "a special concern of the First Amendment, which does not tolerate laws that cast a pall of orthodoxy over the classroom." In describing academic freedom as "a transcendent value to all of us and not merely to the teachers concerned," the Court in Keyishian observed that the "classroom is peculiarly the "marketplace of ideas.", The future of the country, for reasons the Court did not elaborate, "depends upon leaders trained through wide exposure to that robust exchange of ideas which

41. Sweezy, $354 \mathrm{US}$ at 250.

42. Id at 262. In an earlier concurrence that did not refer specifically to academic freedom, Justice Frankfurter, in an opinion joined by Justice Douglas, referred to teachers as "the priests of our democracy." Frankfurter emphasized "the special task of teachers to foster those habits of openmindedness and critical inquiry which alone make for responsible citizens." Wieman v Updegraff, 344 US 183, 196 (1952) (Frankfurter concurring).

43. Sweezy, $354 \mathrm{US}$ at $261,262$. 
discovers truth 'out of a multitude of tongues, [rather] than through any kind of authoritative selection." "44

These passages in Sweezy and Keyishian, though relatively brief and allusive, still remain the Court's fullest discussions of constitutional academic freedom. Like the 1915 Declaration, they emphasized the social importance of critical inquiry in universities in promoting knowledge and serving democratic values. Both the Supreme Court and the 1915 Declaration maintained that the search for truth, in universities as well as in society generally, is never complete and requires free debate about competing ideas that precludes any imposition of ideological orthodoxy. The judicial opinions and the 1915 Declaration even used similar metaphors. The description of the university in the 1915 Declaration as an "intellectual experiment station" closely resembles the description of the classroom in Keyishian as a "marketplace of ideas." Indeed, just as the 1915 Declaration stressed that universities should allow "ideas distasteful to the community as a whole" to "germinate" and perhaps ultimately to become generally accepted, ${ }^{45}$ Justice Holmes, who created the marketplace metaphor for the first amendment invoked by the Court in Keyishian, stressed that society should allow "the expression of opinions that we loathe" because "the best test of truth is the power of the thought to get itself accepted in the competition of the market." 46

The Court's use of the "marketplace of ideas" metaphor in Keyishian also underlined its view, apparent throughout its decisions, that its general free speech jurisprudence-particularly in relation to the search for knowledge and truth and to the key role of free expression in a democracy-applies to the specific context of academic freedom in universities. The Court in Keyishian reiterated in its crucial paragraph identifying academic freedom as "a special concern of the First Amendment" that the "vigilant protection of constitutional freedoms is nowhere more vital than in the community of American schools." This language strengthened the Court's identification of academic freedom with general first amendment values while exacerbating ambiguities about the relationship between them. ${ }^{47}$

The early Supreme Court opinions referring to academic freedom left many questions unanswered. The Court never clarified the relationships among the "special" constitutional right of academic freedom it read into the first amendment, the concept of academic freedom expressed in the 1915 Declaration and broadly accepted within American universities, and the general first amendment right of free speech. Despite significant parallels, these three concepts also contained differences. For example, the focus in the 1915 Declaration on the special training and competence of professors, and

44. 385 US 589, 603 (1967).

45. 1915 Declaration at 167-68; Appendix A at 400 (cited in note 6).

46. Abrams "United States, 250 US 616, 630 (1920) (Holmes dissenting).

47. 385 US at 603, quoting Shelton v Tucker, 364 US 479, 487 (1960). Without referring to academic freedom, Justice Frankfurter similarly emphasized in a previous case that teachers bring the safeguards for freedom of speech, inquiry, and thought in the first amendment "vividly into operation." Wieman, 344 US at 195 (Frankfurter concurring). 
the corresponding importance of peer review to academic freedom, found no echo in Supreme Court opinions. The "marketplace of ideas" metaphor, though in some respects analogous to characterizing the university as an "intellectual experiment station," implies an equality of discourse appropriate in discussions of political ideas by citizens but insensitive to the relevant differences in expertise between professors and students in the classroom. ${ }^{48}$ Numerous general principles of first amendment analysis, moreover, might have little or no relevance to the university context, or might even interfere with legitimate educational decisions by universities based on the content of speech. ${ }^{49}$

\section{A Functional Theory of Constitutional Academic Freedom}

The Supreme Court's brief discussions of academic freedom, whatever their analytical shortcomings and lingering ambiguities, reveal sufficient parallels between academic freedom and the first amendment generally to justify, even if not to require, the Court's constitutionalization of academic freedom as "a special concern of the First Amendment."50 Analyzing academic freedom in terms of the distinctive functions of professors and universities, which is the method of the 1915 Declaration, helps explain, as the Supreme Court never has, the sense in which the academic freedom incorporated into the first amendment is not simply synonymous with the free speech clause. This approach, essentially in agreement with Professor Van Alstyne's classic article, The Specific Theory of Academic Freedom and the General Issue of Civil Liberty, views the speech of professors on matters within their expertise as subject to both greater and lesser constitutional protection than the general speech of all citizens, including speech by professors that does not relate to professional issues. ${ }^{51}$

As the 1915 Declaration emphasized, the basic function of professors in universities-critical inquiry on subjects within their scholarly expertise and the dissemination of the results of their scholarship through teaching and publication-requires freedom from constraints that threaten the independence essential to performing this function. Such constraints would deny the general public the contribution to knowledge and democracy that academic work provides. These social benefits, which the Supreme Court recognized as fundamental first amendment values in Sweezy and Keyishian without tying them in detail to the actual functions of professors in

48. See Byrne, 99 Yale LJ at $\mathbf{2 9 6 - 9 7}$ (cited in note 1).

49. See text accompanying notes 110, 124-25 (discussing emphasis by Justice Stevens on limited applicability of content neutrality in university context).

50. Keyishian, 385 US at 603.

51. Van Alstyne, The Specific Theory of Academic Freedom (cited in note 22). Byrne, 99 Yale L J at 263-65 (cited in note 1), agrees with Professor Van Alstyne's distinction between free speech and academic freedom. 
universities, justify academic freedom under the first amendment as well as under the nonlegal analysis of the 1915 Declaration.

The requirement of scholarly independence for the proper performance of academic work entitles the professor to more freedom from employer control than enjoyed by the typical employee. It makes no sense to expect professors to engage in critical inquiry and simultaneously to allow punishment for its exercise.52 First amendment academic freedom should preclude an administrator or trustee at a public university from forcing a professor to investigate a particular topic or to reach specified conclusions. ${ }^{53}$ Conceivably, constitutional academic freedom might even protect professors at both public and private universities from laws that would apply to other citizens. ${ }^{54}$ The owner of a movie theater could be punished for showing a film declared obscene by a jury in his community though protected by juries elsewhere, but a professor at the adjacent university might have an academic freedom right to show the same film in an advanced course on the regulation of mass media to make the intellectual point that the definition of obscenity involves close questions on which community standards vary. ${ }^{55}$

On the other hand, a professor speaking within his field of expertise may be disciplined without violating constitutional academic freedom for speech that otherwise would be protected under the free speech clause of the first amendment. "The price of an exceptional vocational freedom to speak the truth as one sees it," Professor Van Alstyne astutely observes, "is the cost of exceptional care in the representation of that 'truth,' a professional standard of care."56 Grossly inaccurate speech about the Holocaust, for example, could be cause for dismissing a historian for incompetence, but not for taking any adverse action against a professor in the school of engineering or an employee of the municipal utility commission. ${ }^{57}$

52. Van Alstyne, The Specific Theory of Academic Freedom at 77 (cited in note 22).

53. Id at 75 .

54. An attempt to enforce a law provides the state action that invokes the first amendment at private as well as public universities.

55. The AAUP filed an amicus brief in the Supreme Court of Florida challenging a lower court decision that upheld the seizure of the film "Deep Throat" from a professor of mass communications who had presented an optional viewing to students. The professor showed the movie to give students a "common frame of reference for debate, analogous to what a jury or appellate court might face in deliberating upon the obscenity of a particular work." Roberts v State, 373 S2d 672, 674 (Fla 1979). The AAUP claimed that even if the film were obscene, and therefore unprotected by the speech clause of the first amendment, the independent first amendment right of academic freedom safeguarded the professor from state action. AAUP's Brief as Amicus Curiae at 20-25, Roberts $v$ State, 373 S2d 672 (Fla 1979). The Supreme Court of Florida found that the film was seized in violation of state law, and thus did not reach the constitutional question. $373 \mathrm{~S} 2 \mathrm{~d}$ at 674 . Van Alstyne, The Specific Theory of Academic Freedom at 77-78 (cited in note 22), anticipated such a case.

56. Van Alstyne, The Specific Theory of Academic Freedom at 76 (cited in note 22).

57. In 1977, a professor of electrical engineering at Northwestern University wrote a book entitled The Hoax of the Twentieth Century, asserting that reports of the systematic killing of Jews in Nazi concentration camps were a myth promoted by Zionists to create support for a Jewish state in Palestine. Responding to protests about the university's failure to condemn the professor, its provost stated: "A faculty member's right to have his writing published is not an academic freedom issue. It is a right available to any citizen of the United States under the first amendment of the Constitution. It is a shame when that right is used to insult survivors of concentration camps." Ellen E. Coughlin, Professor's Book on Holocaust Attacked at Northwestern U., Chron Higher Educ 6 (February 7 , 
Constitutional academic freedom thus may provide professors more protection for professional speech and less protection for unprofessional speech than the free speech clause would afford the same statements by nonacademics. Yet using the professional functions of professors to justify constitutional academic freedom means that their expressions on matters unrelated to professional concerns, though possibly covered by the free speech clause, have no status under this "special" first amendment right. An engineer who writes about the Holocaust or who shows a film declared obscene by a local jury has no different first amendment rights than other citizens, because neither expression by the engineer concerns his professional expertise.

This constitutional analysis deviates from the controversial position of the 1915 Declaration, subsequently reiterated by recent scholars, ${ }^{58}$ that the protection of academic freedom should include the extramural speech of professors on subjects outside their academic specialties. Though the drafters of the 1915 Declaration reached this conclusion under the pressure of cases in which universities fired professors for such extramural statements, they apparently relied on a theoretical justification for their pragmatic position. Institutional neutrality, they implied, is the logical counterpart to the faculty independence protected by academic freedom. If faculty cannot be made to answer to the directives of administrators and trustees, then administrators and trustees should not be held responsible for what the faculty says. ${ }^{59}$

This approach, however, has a serious weakness under the logic of the 1915 Declaration itself. The 1915 Declaration repeatedly stressed that academic freedom is justified by the social contributions of expert and independent scholars. When professors do not speak as scholars, therefore, they are not engaging in speech to which academic freedom should apply. The value of institutional neutrality as a distinctive norm stresses that universities should not be held responsible for the aprofessional speech of professors, whether or not such speech is protected by law. ${ }^{60}$ Institutional neutrality, however, relates to academic freedom only to the extent that a

1977). See Seth S. King, Professor Stirs Furor by Saying Nazis' Slaying of Jews is a Myth, New York Times A10 (January 28, 1977) (similar story); Walter Goodman, Tenets of Tenure, New York Times A22 (February 23, 1977) (editorial) (asserting that this professor was appropriately protected by tenure because he was not accused "of carrying out his appointed duties invidiously or incompetently").

58. See, for example, John R. Searle, Two Concepts of Academic Freedom, in Edmund L. Pincoffs, ed, The Concept of Academic Freedom 86-96 (cited in note 22).

59. The norm of institutional neutrality in the 1915 Declaration, though implicit throughout the document, is made explicit by Metzger, 66 Tex L Rev at 1280-81 (cited in note 1).

60. During World War I, President Lowell of Harvard risked the loss of a $\$ 10$ million bequest by refusing to deprive an openly pro-German professor of his chair. "Either the university assumes full responsibility for permitting its professors to express certain opinions in public," Lowell wrote in his annual report, "or it assumes no responsibility whatever, and leaves them to be dealt with like other citizens by the public authorities according to the laws of the land." Metzger, The Age of the University at 228-29 (cited in note 32). Professor Metzger, following the AAUP conception of academic freedom, understandably views Lowell's moral courage as a rare defense of academic freedom during World War I. Id at 228. But I agree with Professor Van Alstyne that in this statement "Lowell was himself making an implicit distinction between alleged abuses of academic freedom (for which Harvard would doubtless admit its responsibility of review of its own faculty) and alleged abuses of 
professor's speech, inside or outside the university, concerns a matter of professional expertise.

Whatever one's view about the application of academic freedom by the 1915 Declaration to the aprofessional extramural speech of professors, additional barriers to protecting such speech arise under a constitutional definition of academic freedom. The drafters of the 1915 Declaration did not have to address the free speech rights of other occupations. They could easily have conceded that the neutrality they urged for universities should also apply to other institutions, while adding that this issue was beyond the appropriate concern of the 1915 Declaration, which focused on the role of university professors. Yet the free speech clause of the first amendment, unlike the 1915 Declaration, covers the speech of all citizens. If academic freedom has a special meaning under the first amendment, it must be distinguished from the general free speech clause. The distinctive professional functions of professors provide the basis for applying a special first amendment concept to them. But what is the first amendment justification for treating the aproressional speech of professors differently from the speech of anyone else?

The only plausible justification is that the line between professional and aprofessional speech may be controversial, and that protection for clearly aprofessional speech is needed to give "breathing room" to the professional speech that is the special subject of academic freedom. Such a drastic prophylactic rule is unnecessary and would be likely to generate more resentment against the "special pleading" of professors than even a narrow and convincing conception of academic freedom inevitably does. A generous definition of professional speech is a feasible and better response to this legitimate concern.

There are legitimate first amendment reasons for protecting the political speech of public employees generally. Indeed, the Supreme Court has done so while rejecting the "right/privilege" distinction popularized by Holmes. But as the Supreme Court has recognized, it is the free speech clause, not the special first amendment right of academic freedom, that provides the constitutional basis for this protection. ${ }^{61}$

\section{$\mathrm{V}$ \\ Hints of Judicial Recognition of a Specific Theory of ACADEMIC Freedom}

The Supreme Court has not explicitly distinguished the specific theory of academic freedom from the general protection of the first amendment, and often refers interchangeably to academic freedom and the right to political expression. Yet, as a number of recent lower court decisions indicate, the judicial application of a specific theory of academic freedom would require

free speech and the general issue of civil liberty." Van Alstyne, The Specific Theory of Academic Freedom at 80 (cited in note 22).

61. See Van Alstyne, The Specific Theory of Academic Freedom at 68-70, 80-81 (cited in note 22). 
only an elaboration, rather than a reversal, of the current undifferentiated approach. For example, cases involving the rejection of Marxist candidates for appointment have observed that universities violate academic freedom by discharging or refusing to hire a professor "because of his or her political, philosophical, or ideological beliefs."'62 Typically, these cases did not attempt to identify whether the Marxist speech related to academic or political issues. The opinions did reflect, however, the conclusion that the professors' Marxist views are protected by the first amendment in both contexts. It would not be difficult for courts to refine this approach by applying the specific theory of academic freedom to Marxist speech by professors on professional matters, and general first amendment principles to Marxist speech by professors on aprofessional, political issues.

Some decisions, moreover, have protected the specifically academic speech of professors. The first case produced by the recent wave of institutional policies on offensive speech focused on their impact in the classroom. For example, a teaching assistant in a course entitled "Comparative Animal Behavior" wanted to include as a topic in his discussion group the hypothesis that biological differences account for the greater ability of men than of women to perform certain mental tasks based on spatial relationships. The teaching assistant argued, and the judge agreed, that some students and teachers would regard this theory as sexist and that its presentation could subject him to prosecution for harassment under applicable university policies. Without referring explicitly to academic freedom, the judge held that the university policies violated the first amendment. ${ }^{63}$

Other cases do cite academic freedom in addressing the first amendment protection for academic speech and seem at least implicitly to recognize a distinction between academic freedom and general free speech under the first amendment. Judge Posner indicated that first amendment academic freedom may give professors more protection than the first amendment provides to members of the general public. He reasoned that professors may express ideas in places on campus that are not public forums and from which members of the general public may therefore be excluded. ${ }^{64}$ Another judge identified more directly a distinction between academic freedom and general first amendment rights. He based his finding of a general first amendment violation on the university's failure to renew the appointment of a Marxist professor due to his aprofessional speech and associations: his belief in communism and his membership in the Progressive Labor Party. This conclusion allowed the judge to finesse the university's claim that it acted because the professor inappropriately injected Marxism into the classroom.

62. Ollman $v$ Toll, 518 F Supp 1196, 1202 (D Md 1981), aff'd, 704 F2d 139 (4th Cir 1983); Franklin $v$ Atkins, 409 F Supp 439, 445 (D Colo 1976), aff'd, 562 F2d 1188 (10th Cir 1977). Both opinions borrowed this language from Justice Douglas's dissent in Board of Regents $v$ Roth, 408 US 564,581 (1972).

63. Doe v University of Michigan, 721 F Supp 852, 860, 864-67 (ED Mich 1989).

64. Piarowski v Illinois Community College Dist., 759 F2d 625, 629-31 (7th Cir 1985). 
The judge assumed, without deciding, that teaching history from a Marxist orientation would be covered under the first amendment's protection of academic freedom, especially given the fact that other professors in the university's history department taught their courses from various competing perspectives. ${ }^{65}$

Another judge implicitly acknowledged the added limitations on professors imposed by a specific theory of academic freedom. A faculty member claimed that the department of political science denied him tenure because he had associated with the Central Intelligence Agency. In a separate opinion, Judge Kaufman criticized the majority for assuming, without deciding, that this association is protected by the first amendment. According to Judge Kaufman, the candidate's behavior in covertly providing to the CIA information he gathered during academic trips abroad cast legitimate doubt on his commitment to the goals and principles of scholarship, threatened the scholarly pursuits of his colleagues, and unjustifiably inhibited departmental collegiality. Judge Kaufman did not address the relationship between the first amendment and academic freedom. Yet his reasoning closely parallels Professor Van Alstyne's more fully elaborated position that the social value of critical inquiry justifying constitutional protection for individual academic freedom may constrain professors in ways that would be left unrestricted by the application of the general first amendment rights of speech and association to other citizens. ${ }^{66}$

These recent judicial opinions identify the importance of academic speech by professors, occasionally distinguish it from speech in other contexts, and recognize that it may be subject to both greater and lesser protection than the first amendment usually provides. They are cause for optimism that courts can develop a coherent and convincing specific conception of constitutional academic freedom under the first amendment that differs from the free speech rights all citizens possess.

\section{VI}

Constitutional Academic Freedom As a Specific Instance of the First Amendment in Institutional Context

The distinctive functions of professors and universities provide a convincing justification for the Court's ambiguous incorporation of academic freedom as "a special concern" of the first amendment. Yet special treatment for a particular occupation or institution, even if analytically sound under general first amendment principles, creates understandable skepticism, especially given the accurate perception that citizens have rights to equal protection under the first amendment. The argument for a constitutional right of academic freedom can be substantially strengthened by viewing it not

65. Cooper $v$ Ross, 472 F Supp 802, 813-14 (ED Ark 1979).

66. Selzer v Fleisher, 629 F2d 809, 814-17 (2d Cir 1980) (Kaufman concurring in part and dissenting in part). 
primarily as a special right unique to professors, but as a specific application of the broader principle that the institutional context of speech often has first amendment significance. Under this approach, constitutional academic freedom is simply a convenient name to describe special speech rules governed by the functions of professors and universities, just as other special speech rules, which may not have been separately named, are required by the distinctive yet different functions of institutions as varied as prisons, libraries, the military, the civil service, public schools, and the media.

\section{A. Tinker and Its Progeny}

The role of institutional context in first amendment interpretation, though made clear by many Supreme Court decisions, has not been sufficiently highlighted in first amendment theory. ${ }^{67}$ The Court's most explicit recognition of institutional context occurred in Tinker $v$. Des Moines Independent Community School District, a case upholding the right of junior and senior high school students to wear black armbands to protest American involvement in Vietnam. The Court reasoned that the first amendment rights of teachers and students, which they do not "shed . . . at the schoolhouse gate," must be "applied in light of the special characteristics of the school environment." 68 While stressing the legitimate need of school officials to punish speech that interferes with educational functions, the Court did not find any evidence in the record that wearing the armbands would cause such interference. The Court insisted that "a mere desire to avoid the discomfort and unpleasantness that always accompany an unpopular viewpoint" did not constitute a sufficient reason to give students lesser first amendment rights in the school environment than elsewhere. ${ }^{69}$

While some cases, like Tinker itself, conclude in a particular factual setting that the "special characteristics" of an institution do not require any modification of general first amendment rights, ${ }^{70}$ other cases, frequently citing Tinker, have emphasized that first amendment protections vary with institutional context. Decisions make clear, for example, that the functions of

67. Robert C. Post, Between Governance and Management: The History and Theory of the Public Forum, 34 UCLA L Rev 1713 (1987), is a major exception. Professor Post stresses that the government can regulate speech to achieve the effective functioning of its own institutions. See also C. Edwin Baker, Press Rights and Government Power to Structure the Press, 34 U Miami L Rev 819, 824 (1980) (asserting first amendment's press clause can be interpreted "as granting special constitutional protection to a particular institution, the press"); Stanley Ingber, Rediscovering the Communal Worth of Individual Rights: The First Amendment in Institutional Contexts, 69 Tex L Rev 1, 101-02 (1990) (arguing communal as well as individual interests should be weighed in evaluating claims that institutional functions require constraints on speech).

68. Tinker $v$ Des Moines School Dist., 393 US 503, 506 (1969).

69. Id at 509. In his dissent, Justice Black disagreed with the majority's characterization of the record. Citing specific incidents, Black claimed that the record contained overwhelming evidence that the armbands "took the students' minds off their classwork and diverted them to thoughts about the highly emotional subject of the Vietnam war." Id at 518.

70. See, for example, Wood v Georgia, 370 US 375, 393-94 (1962) (sheriff's job responsibilities in administration of justice do not impose fewer first amendment rights than other citizens to criticize judicial behavior; no evidence suggests sheriff's criticisms interfered with proper performance of his official functions). 
the media and libraries require substantial scope for the exercise of free expression, while the functions of the military and prisons justify restrictions on speech citizens otherwise enjoy.

Two cases since Tinker illustrate that its focus on "the special characteristics of the school environment" can limit as well as protect the first amendment rights of students. While reiterating that tolerance of divergent views are among the fundamental democratic values schools should inculcate, ${ }^{71}$ the Court has held that "pervasive sexual innuendo"72 in a student speech at a high school assembly could sufficiently "undermine the school's basic educational mission" 73 to justify the student's suspension. This "vulgar and lewd"74 language occurred during a speech nominating another student for an office in the school's student government. The Court acknowledged that the first amendment would protect the identical speech uttered by an adult during a political campaign, but denied that "the same latitude must be permitted to children in a public school." 75

In a subsequent case, the Court upheld the decision by a high school principal to censor from a school newspaper stories dealing with pregnancy and divorce. The Court reasoned that the first amendment does not apply to "school-sponsored expressive activities" if the actions by the school authorities "are reasonably related to legitimate pedagogical concerns." 76 Emphasizing that the standards for student speech disseminated under school auspices legitimately "may be higher than those demanded by some newspaper publishers or theatrical producers in the 'real' world," 77 the Court upheld the principal's conclusion that the student editors had failed to follow sound journalistic practices regarding the treatment of controversial issues and the need to protect personal privacy. ${ }^{78}$

The Court has relied on the special characteristics of several other institutions to limit first amendment rights. In denying protection to antiwar speech at a military base, the Court reasoned that "the different character of the military community and of the military mission requires a different application" of the first amendment. The fundamental military requirements of obedience and discipline, the Court added, "may render permissible within the military that which would be constitutionally impermissible outside it."79

71. Bethel School Dist. v Fraser, 478 US 675, 681 (1986).

72. Id at 683 .

73. Id at 685 .

74. Id.

75. Id at 682 .

76. Hazelwoad School Dist. v Kuhlmeier, 484 US 260, 273 (1988). The Court distinguished the school-sponsored student expression in Hazelwood from the nonsponsored student expression in Tinker. Id at $272-73$

77. Id at 272 .

78. Id at 276. Dissenting, Justice Brennan asserted that the school "censorship served no legitimate pedagogical purpose." Id at 289.

79. Parker $v$ Levy, 417 US 733, 758 (1974). The Court subsequently cited the military interest in troop readiness in rejecting a first amendment challenge to regulations requiring Air Force personnel to receive approval from their commanders before circulating petitions on Air Force bases. Brown $v$ Glines, 444 US 348 (1980). 
The Court similarly has held that a prison inmate retains first amendment rights only to the extent that they "are not inconsistent with his status as a prisoner or with the legitimate penological objectives of the corrections system." 80 Upholding regulations forbidding press interviews with individual inmates, the Court observed that under prior, less restrictive rules, inmates who were interviewed gained notoriety and influence within the prison and became severe disciplinary problems. ${ }^{81}$

In a context far less generally restrictive than a military base or a prison, the Court also relied on special institutional functions to reject a first amendment attack on prohibitions in the Hatch $\mathbf{A c t}^{82}$ against active participation by civil servants in partisan political activities. The Court agreed with the legislative judgment that these prohibitions are justified by the valid purposes of preventing improper influence and corruption while preserving efficient and effective government services. ${ }^{83}$

On the other hand, a Court plurality has cited the emphasis in Tinker on institutional context to provide greater first amendment rights in a school library than in a classroom. A local school board cannot remove books from a school library, the opinion reasoned, because "the special characteristics of the school library make that environment especially appropriate for the recognition of the first amendment rights of students." 84 In response to the school board's claimed discretion to inculcate community values, the plurality highlighted "the unique role of the school library." The opinion distinguished "the compulsory environment of the classroom," where absolute discretion by the board in determining curriculum might be justified by its inculcative functions, from "the regime of voluntary inquiry" that characterizes the school library, where inculcation is not appropriate. ${ }^{85}$ Without contrasting the distinctive aspects of the classroom and the library, Justice Blackmun observed in his concurrence that "the unique environment of the school" both allows and limits the immunity of school officials from first amendment restraints. The inculcative functions of schools, Blackmun concluded, must be reconciled with commitment to "diversity of thought," which is itself a social value that schools should inculcate, and which is protected by the "first amendment's bar on 'prescriptions of orthodoxy." "86

\section{B. Media Cases}

Without citing Tinker, the Court has relied on the distinctive functions of the media in extending broad first amendment rights. The Court held that a legislative ban on editorializing by noncommercial educational broadcasting

80. Pell v Procunier, 417 US 817, 822 (1974).

81. Id at 831-32. Saxbe v Washington Post Co., 417 US 843 (1974), reaches the same conclusion.

82. 5 USC $\$ 7324(\mathrm{a})(2)(1989)$.

83. United States Civil Serv. Comm 'n v National Ass 'n of Letter Carriers, 413 US 548, $564-67$ (1973).

84. Board of Educ. v Pico, 457 US 853, 868 (1982) (emphasis in original). Justices Brennan, Marshall, and Stevens formed the plurality.

85. Id at 869 .

86. Id at 879 
stations, though enacted with the laudable aim of preventing them from becoming agencies of government propaganda, violated the first amendment. According to the Court, these stations require first amendment protection of "journalistic freedom" in order to serve their function of informing the public. ${ }^{87}$

Numerous judicial decisions, sometimes relying on the first amendment generally and sometimes citing its press clause specifically, have similarly attributed constitutional significance to the special role of newspapers in contributing to the discussion of public affairs. ${ }^{88}$ After several concurring and dissenting opinions by other members of the Court supported press efforts to enter prisons, ${ }^{89}$ Chief Justice Burger wrote a plurality opinion granting the general public and the press an equal first amendment right of access to a criminal trial. ${ }^{90}$ In the previous prison cases, the Court majority had observed with approval that, as a matter of practice, the press has enjoyed significantly more access than members of the general public to prisons and prisoners. These cases, however, rejected claims that the first amendment mandates such a result. ${ }^{91}$ In requiring press and public access to a criminal trial, Burger also took judicial notice of separate press rights such as special seating and priority of entry. Going beyond the simple judicial approval of extra access by the press in the prison cases, Burger tied the favorable treatment of the press to first amendment concerns. He made the historical point that public knowledge of criminal trials, which once came from personal observation or word of mouth, is now generally received through print and electronic journalism. This historical transformation, Burger maintained, "validates the media claim of functioning as surrogates for the public." In this important sense, the media make a unique contribution to public understanding of the criminal justice system. ${ }^{92}$

Although Chief Justice Burger clearly viewed special treatment of the press, justified by its institutional function of informing the public, as serving

87. FCC $v$ League of Women Voters of Califormia, 468 US 364, 397-99, 402 (1984).

88. See, for example, Minneapolis Star \& Tribune Co. $v$ Minnesota Comm'r of Revenue, 460 US 575 (1983) (emphasizing importance of an explicit guarantee of freedom of the press in Constitution, id at 584; threat of differential taxation of press can operate "effectively as a censor to check critical comment by the press, undercutting the basic assumption of our political system that the press will often serve as an important restraint on government," id at 585); Miami Herald Publishing Co. v Tornillo, 418 US 241, 258 (1974) ("First Amendment guarantees of a free press" preclude government regulation of "exercise of editorial control and judgment" regarding "treatment of public issues and public officials"); Sheppard v Maxwell, 384 US 333, 350 (1966) (press subjects entire criminal process to "public scrutiny and criticism"); Mills v Alabama, 384 US 214 (1966) (emphasizing consensus that major purpose of first amendment is "to protect the free discussion of governmental affairs," id at 218-19; first amendment has "specifically selected the press . . . to play an important role in the discussion of public affairs," id).

89. See, for example, Houchins v KQED, Inc, 438 US 1, 16 (1978) (Stewart concurring); id at 19 (Stevens dissenting); Saxbe v Washington Post Co., 417 US 843, 850 (1974) (Powell dissenting); Pell, 417 US at 835 (Powell concurring in part and dissenting in part); id at 836 (Douglas dissenting).

90. Richmond Newspapers, Inc. v Virginia, 448 US 555 (1980).

91. Saxbe, 417 US at 849-50; Pell, 417 US at $831 \mathrm{n} 8,834-35$

92. Richmond Newspapers, Inc., 448 US at $572-73,577 \mathrm{n} 12$. Subsequent cases reiterated this point while expanding press access. See, for example, Press-Enterprise Co. v Superior Court, 478 US 1 (1986) (recognizing qualified first amendment right of access to preliminary hearings). 
vital first amendment purposes, he took pains not to assert more first amendment rights for the press than for the general public. This paradoxical view is best revealed in opinions that anticipated Burger's approach while advocating special press access to prisons. For example, Justice Powell cited the "constitutionally established role of the news media" as justifying greater access to prisons than is permitted the general public. ${ }^{93}$ Powell stressed that it is "hopelessly unrealistic" for most citizens to obtain information about important public issues without the assistance of the press, and referred to the press as "an agent of the public," whose "underlying right" to information requires special rules giving the press favored treatment.94 Yet Powell agreed with the majority that the first amendment does "not create special privileges for particular groups or individuals," including journalists. According to Powell, "neither any news organization nor reporters as individuals have constitutional rights superior to those enjoyed by ordinary citizens."95

In another case, Justice Stewart also accepted the majority's position that the first amendment does not "guarantee the press any basic right of access superior to that of the public generally." Stewart added, however, that he, unlike the majority, did not "view 'equal access' as meaning access that is identical in all respects." Given the dependence of the general public on the press for information, Stewart reasoned that "the concept of equal access must be accorded more flexibility" to allow the press greater access than the general public. ${ }^{96}$ Restrictions reasonable for the general public, Stewart claimed, may be unreasonable, and even unconstitutional, as applied to journalists. Stewart supported his position by emphasizing the existence of a separate press clause in the first amendment, which he considered "no constitutional accident, but an acknowledgment of the critical role played by the press in American society." 97

I find incoherent the view articulated in many of these opinions that the institutional functions of the press recognized by the first amendment should afford journalists special benefits, but that those benefits should not be interpreted as giving the press a more favored position under the first amendment. Justice Stewart's insistence that "equal" access does not mean "identical" access highlights the problems with this view. Clearly uncomfortable about recognizing additional first amendment rights not generally available to the public, many justices apparently consider the underlying public benefits justifying special press rights as negating any claim that these rights reflect greater first amendment protection for journalists.

A more persuasive analysis would require overcoming the Court's squeamishness about granting unique first amendment rights to a particular profession. The Court should frankly acknowledge, as it seemed to suggest in

93. Saxbe, 417 US at 864 (Powell dissenting).

94. Id at 863-64.

95. Id at 857 .

96. Houchins, 438 US at 16 (Stewart concurring).

97. Id at 17. 
a case prohibiting differential taxation of the press, ${ }^{98}$ that special rights for the press do constitute additional protection under the first amendment, and justify that protection by the public benefits it freely acknowledges the press performs. Just as the institutional functions of the military and the corrections system permit restrictions on general first amendment rights, so the institutional functions of the press should mandate greater first amendment protection than other citizens enjoy. Whether restricting or expanding general first amendment rights, the ultimate contribution to the public derived from the effective operation of vital organizations justifies these special rules tailored to different institutional purposes.

\section{Institutional Context and the University}

Cases constitutionalizing academic freedom also indicated that the university is an institution in which first amendment rights have special meaning. Chief Justice Warren's pivotal opinion in Sweezy emphasized "the esser,tiality of freedom" in universities and recognized that "[s]cholarship cannot flourish in an atmosphere of suspicion and distrust."99 The South African statement quoted at length in Justice Frankfurter's concurrence defined a university as "characterized by a spirit of free inquiry," whose "business" is "to provide that atmosphere which is most conducive to speculation, experiment and creation." 100 Keyishian added that the university "classroom is peculiarly the 'marketplace of ideas,'" which cannot function under "a pall of orthodoxy."101

More recent higher education cases have tied the intervening focus in Tinker on the "special characteristics" of an institutional environment to the earlier first amendment protection of academic freedom in Sweezy and Keyishian. The two major Supreme Court decisions applying the Tinker analysis to universities acknowledged that the distinctive institutional mission of the university may justify fewer first amendment rights on campus than citizens otherwise enjoy. ${ }^{102}$ In both cases, however, the Court refused to find such a justification and emphasized that in some respects the first amendment has particular vitality in universities.

98. See Minneapolis Star, 460 US at $583-84$ (referring to inclusion of an "explicit guarantee of freedom of the press" as "substantial evidence that differential taxation of the press would have troubled the Framers of the First Amendment").

Dissenting from the Court's refusal to grant a reporter's privilege against responding to a grand jury subpoena, Justice Douglas more explicitly advocated special rights for the press. He urged an absolute privilege for reporters based on the "preferred position" of the press "in our constitutional scheme." This "preferred position," Douglas stressed, is not designed "to set newsmen apart as a favored class, but to bring fulfillment to the public's right to know." Branzburg v Hayes, 408 US 665 , 721 (1972) (Douglas dissenting). See Baker, $34 \mathrm{U}$ Miami L Rev at 829 (cited in note 67) (social functions of the press "justify institutional rights beyond those already accorded by the free speech doctrine").

99. 354 US at 250.

100. Id at 262-63.

101. 385 US at 603 .

102. Widmar $v$ Vincent, 454 US 263, 267-68 n5 (1981); Healy $v$ James, 408 US 169, 180-81 (1972). 
Overturning the refusal of a college president to recognize a campus chapter of Students for a Democratic Society ("SDS"), the Court in Healy v. James found no evidence to support the president's conclusion that the chapter posed a significant threat of disruption. The Court acknowledged that the first amendment does not protect organizations that "infringe reasonable campus rules, interrupt classes, or substantially interfere with the opportunity of other students to obtain an education," 109 and remanded the case for a determination of whether the local SDS chapter would commit itself to following legitimate university regulations. ${ }^{104}$ The majority implied what Justice Rehnquist's concurrence made clear: "The government as employer or school administrator may impose upon employees and students reasonable regulations that would be impermissible if imposed by the government upon all citizens." 105 Yet the majority also warned against inferring from its appreciation of the university's need for order any hint that first amendment "protections should apply with less force on college campuses than in the community at large. Quite to the contrary," the Court added, invoking prior decisions incorporating academic freedom within the first amendment, it is particularly important to protect first amendment rights in universities. ${ }^{106}$

In Widmar $v$. Vincent, a subsequent case upholding the right of a student group to meet on campus, the Court emphasized that the special characteristics of a university can permit restrictions on speech that would violate the first amendment if applied in a public forum. The Court stressed that a university's educational mission can justify "reasonable regulations compatible with that mission upon the use of its campus and facilities." 107 Yet the Court invalidated a university's rules prohibiting the use of its facilities by an organization of evangelical Christian students. The university's institutional mission of providing a "secular education,"108 the Court concluded, was not sufficiently "compelling" 109 to allow a content-based exclusion of religious speech inconsistent with both the free exercise and the free speech clauses of the first amendment.

Concurring, Justice Stevens went further and challenged the very application of traditional first amendment concepts to the university setting. He emphasized that universities, in "performing their learning and teaching missions," routinely and appropriately make decisions based on the content of speech, a suspect category in general first amendment jurisprudence. Selecting the professors to appoint and reward, choosing the books to purchase for the library, developing the curriculum, and allocating scarce university resources and facilities among students groups all require evaluation of the content of expressive activities. Legal terms such as

103. Healy, 408 US at 189 .

104. Id at 194 .

105. Id at 203 (Rehnquist concurring).

106. Id at 180-81.

107. 454 US $263,268 \mathrm{n} 5$.

108. Id at 268 (emphasis in original).

109. Id at 276 . 
"compelling state interest" and "public forum," Stevens complained, not only distract from the need to focus on the distinctive aspects of the university environment, but "may needlessly undermine the academic freedom of public universities." 110

Even when asserting that the first amendment should apply with particular force in the university, the Court has never suggested that members of the university community may in some contexts have more first amendment protection than the general public. At most, some of the Court's opinions have indicated that restrictions on speech that may be appropriate for younger students would violate the first amendment in the university context. In determining the constitutionality of school regulations, the Court has cited differences in the "emotional maturity" of students,"11 and Chief Justice Rehnquist, while advocating greater discretion for a school board than the majority of his colleagues allowed, conceded that there are fewer inculcative or pedagogical reasons to limit access to ideas in universities. ${ }^{112}$ For example, Rehnquist distinguished "the broad ranging inquiry available to university students" from the need for "an orderly exposure to relevant information" at earlier stages of education. 113

Yet as in the press cases, it makes sense to assert that the functions of a particular profession that benefit the general public can justify greater first amendment protection than other citizens enjoy. Just as "journalistic freedom"114 enables the media to make their distinctive professional contribution to the public's first amendment right to learn about and criticize government activities, academic freedom enables professors to serve the public's first amendment interests in fostering critical inquiry and knowledge vital to democracy and civilization. The Court cited these public benefits in identifying academic freedom as a special right under the first amendment. ${ }^{115}$ However, constitutionalizing academic freedom seems much less like elitist favoritism for a particular profession when it is appropriately viewed as but one example of the general proposition that first amendment principles vary with institutional context.

Special first amendment protection for journalists and professors benefit the public as much as special restrictions on the first amendment rights of

110. Id at 277-81. Concurring in Healy, Justice Rehnquist stressed that first amendment cases dealing with criminal sanctions are largely inapplicable in cases where the government is the employer or college administrator. First amendment cases, Rehnquist added, "are not fungible goods." 408 US at 203.

111. Hazelwood, 484 US at 272. See also id at 271; Edwards $v$ Aguillar, 482 US 578, 606-07 (1987) (Powell concurring); Widmar, 454 US at $274 \mathrm{n} 14$. The Supreme Court recently has declined to grant a writ of certiorari in a case that relied on the differences between adult college students and minor high school students to deny college administrators "the same broad discretion in controlling their curriculum as school administrators at the elementary and secondary level." DiBona $v$ Matthews, 220 Cal App3d 1329, 1346, 269 Cal Rptr 882, 892 (1990), cert denied, 59 USLW 3402 (No 90-598) (US ed, December 3, 1990).

112. Pico, 457 US at 909, 914 (Rehnquist dissenting).

113. Id at 914 .

114. See note 87 and accompanying text.

115. See notes 41-47 and accompanying text. 
prisoners and military personnel. Moreover, as a functional analysis of academic freedom reveals, ${ }^{116}$ the same professional responsibilities that justify additional first amendment rights of professors may also allow limitations on their speech that do not apply to others. For example, a professor who plagiarizes a scholarly paper may be disciplined for a gross violation of professional ethics, while a prisoner, who in many respects has fewer first amendment protections than other citizens, could probably not be punished for copying verbatim the clemency petition of a fellow inmate.

Concern about creating additional first amendment rights for particular professions also should be assuaged by the prevalence throughout the law of legal protections based on distinctive job functions, even in expressive contexts not explicitly covered by the first amendment. The speech or debate clause of the Constitution gives legislators an absolute privilege for statements made during legislative debates in order to protect the independence of Congress as a separate branch of government. ${ }^{17}$ Absolute common law privileges in defamation cases similarly protect judges, legislators, and executive officers of government in the performance of functions that ultimately benefit the public. ${ }^{118}$ Relying on the first amendment to give special protection to the speech of journalists and professors that also benefits the public seems equally justifiable.

In retrospect, it may be unfortunate that the term academic freedom, with its many and evolving connotations within the university community, became constitutionalized. Conceptual confusion inevitably results when the same term has different meanings in constitutional and academic discourse. The difficulties in distinguishing constitutional academic freedom from general free speech principles are exacerbated by the additional problem of untangling constitutional from professional definitions of academic freedom. It might have been wiser for the Court to have developed a separate term, such as "academic speech," 119 to refer to distinctive first amendment rights in the university context. Academic freedom, however, has acquired constitutional significance. Rather than abandon this usage after more than a generation, it makes more sense to focus on how constitutional academic freedom, which can legitimately be considered an example of applying the first amendment in institutional context, overlaps with and differs from both professional definitions of academic freedom and general free speech doctrines.

116. See notes 50-61 and accompanying text.

117. See, for example, Hutchinson v Proxmire, 443 US 111 (1979); United States v Brewster, 408 US 501 (1972); United States v Johnson, 383 US 169 (1966).

118. W. Page Keeton, et al, Prosser and Keeton on Torts 815-23 (West, 5th ed 1984). I am grateful to Guy Wellborn for suggesting the relevance of these privileges to analogous first amendment protection based on the speaker's function.

119. See Byrne, 99 Yale L J at 258-61 (cited in note 1) (using "academic speech . . to encompass both scholarship and teaching"). 


\section{VII}

\section{The Development of Institutional Academic Freedom Under THE First AMENDMEnT}

While constitutionalizing academic freedom in Sweezy, Chief Justice Warren's plurality opinion and Justice Frankfurter's concurrence tied the first amendment values of critical inquiry and the search for knowledge to the independence of both professors and universities from state intrusion. Yet a distinctive conception of institutional academic freedom remained only latent throughout the McCarthy-era cases, largely because they involved state actions against individual lecturers and professors as in Sweezy and Keyishian rather than direct conflicts between individuals and universities. More recently, however, universities have relied on an institutional right of academic freedom to defend themselves both against the state and against students, professors, and members of the general public. These cases have prompted the courts to consider in new contexts the institutional component of academic freedom. ${ }^{120}$

Court opinions did not focus on institutional academic freedom until 1978, when Justice Powell's opinion provided the fifth vote for the majority in Regents of the University of California v. Bakke. ${ }^{121}$ Powell reiterated that "[a]cademic freedom, though not a specifically enumerated constitutional right, long has been viewed as a special concern of the First Amendment." He maintained that " 'the four essential freedoms' of a university," identified in the South African statement quoted at length in Justice Frankfurter's concurring opinion in Sweezy, "constitute academic freedom." A university, according to the statement, must be able "to determine for itself on academic grounds who may teach, what may be taught, how it shall be taught, and who may be admitted to study."122 The Court quoted this language from Sweezy again in Widmar $v$. Vincent, ${ }^{123}$ and Justice Stevens, concurring in Widmar, referred to "the academic freedom of public universities."124 Citing Sweezy and Bakke, Justice Stevens stressed that educational decisions based on the content of speech "should be made by academicians, not by federal judges." 125 Ironically, even while underlining the institutional component of academic freedom, the Court in both Bakke and Widmar relied on countervailing constitutional values to overrule the universities' decisions. ${ }^{126}$

120. The Supreme Court protected the institutional autonomy of universities through other doctrines before it constitutionalized academic freedom in Sweezy. See note 24.

121. 438 US 265 (1978).

122. Id at 312, citing Sweezy, 354 US at 263, citing The Open Universities in South Africa 10-12 (a statement of a conference of senior scholars from the University of Cape Town and the University of Witwatersrand).

123. 454 US at 276.

124. Id at 278 (Stevens concurring).

125. Id at 279. See also id at $279 \mathrm{n} 2$

126. In Bakke, Justice Powell emphasized that the challenged admissions program violated the 14 th amendment by focusing "solely on ethnic diversity." 438 US at 315 . He cited the admissions program at Harvard College as an example that met 14th amendment requirements. Under Harvard's program, "race or ethnic background may be deemed a 'plus' in a particular applicant's 
Two important cases, Princeton University v. Schmid 127 and University of Pennsylvania v. Equal Employment Opportunity Commission, ${ }^{128}$ illustrate the range of complicated issues raised by claims of institutional academic freedom. After discussing these cases, I explore the possibility that institutional academic freedom has a different meaning for state universities than for private ones and discuss the relationship between state legislatures and the universities they create.

\section{A. Princeton University v. Schmid}

A case at Princeton University first attracted substantial attention to the potential tension between the developing judicial recognition of institutional academic freedom and the individual academic freedom of professors that historically had been the primary focus of this concept. Despite the objections of many of its own faculty, Princeton relied on the first amendment to resist any judicial review of its policies regulating access by outsiders to campus facilities. The case arose when Chris Schmid, a member of the United States Labor Party who had no affiliation with the university, distributed and sold on the campus material dealing with the party and the mayoral campaign in nearby Newark. Existing Princeton regulations prohibited any person without a university connection or sponsorship from entering the campus to solicit support or contributions. Schmid was arrested and convicted of trespass. Although the Supreme Court ultimately held that new, more permissive university regulations rendered the original dispute moot, ${ }^{129}$ this litigation generated an important debate about the meaning of institutional academic freedom.

In overturning Schmid's conviction, the Supreme Court of New Jersey relied on the free speech provision of the state constitution, which it acknowledged to be "more sweeping in scope than the language of the first amendment." 130 Contrasting the state action requirement of the fourteenth amendment, the court observed that the free speech rights in the New Jersey Constitution are enforceable against private as well as public bodies. ${ }^{131}$ The court recognized that the New Jersey Constitution also protects ownership of private property, and viewed its task as balancing Princeton's property rights against Schmid's expressive rights.

In analyzing these competing claims, the court revealed remarkable sensitivity to the institutional context of campus speech. Citing Princeton's own regulations lauding the importance of free inquiry and free speech in

\footnotetext{
file, yet it does not insulate the individual from comparison with all other candidates for the available seats." Id at 317. In Widmar, the majority and Justice Stevens agreed that the University's fear of violating the establishment clause was unwarranted and thus could not justify its content-based restriction on the first amendment rights of students denied a meeting place on campus. 454 US at 278; id at 280-81 (Stevens concurring).

127. 455 US $100(1982)$.

128. $110 \mathrm{~S}$ Ct 577 (1990).

129. 455 US at 103.

130. State v Schmid, 84 NJ 535, 557, 423 A2d 615, 626 (1980).

131. Id at 565-66, $423 \mathrm{~A} 2 \mathrm{~d}$ at 631 .
} 
achieving the university's declared purpose of promoting knowledge, the court concluded that Schmid's presence on campus was "entirely consonant with the University's expressed educational mission."132 The court acknowledged that "needs, implicating academic freedom and development, justify an educational institution in controlling those who seek to enter its domain" and require substantial judicial deference to university "autonomy and self-governance." 133 Yet it reversed Schmid's conviction because Princeton's regulations contained no reasonable standards relating limitations on expressive freedoms to legitimate educational goals. ${ }^{134}$

In its jurisdictional statement to the United States Supreme Court, Princeton complained that its academic freedom protected by the first amendment was violated when the Supreme Court of New Jersey arrogated to itself "the ancient right of a university community to determine how its educational philosophy may best be implemented."135 According to Princeton, a private university's choice of educational philosophy, however broad, orthodox, or eccentric, is immunized by first amendment academic freedom from interference by the state. Princeton insisted that no governmental body is constitutionally competent to determine whether a private university has acted in accordance with its educational objectives. Princeton conceded that "the university cannot claim its academic freedom as a shield against state rules concerning health, safety and like matters," but immediately added that correspondingly "the state cannot use its police powers to control in any way the intellectual activities of the university."136

Princeton's main brief reiterated and elaborated this theme, asserting that first amendment academic freedom provides greater protection to private than to public universities. The educational judgments of public universities, like those of private universities, are protected against interference from other state entities. Public universities, however, are also subject to the constraints on all government action imposed by the prohibitions in the first and fourteenth amendments against the state's adoption of a particular religious or ideological viewpoint. Princeton maintained that private universities, by contrast, are absolutely unconstrained in their choice of educational philosophy. ${ }^{137}$ Stressing "the interrelation of expressive and property rights," Princeton made the historical observation that control by universities over their property helped to provide an educational "atmosphere conducive to learning and to the interchange of ideas between faculty and students."138 That Princeton chose an expansive view of free expression on its campus, the

132. Id at $564,423 \mathrm{~A} 2 \mathrm{~d}$ at 631 .

133. Id at 566-67, $423 \mathrm{~A} 2 \mathrm{~d}$ at 632 .

134. Id at $567,423 \mathrm{~A} 2 \mathrm{~d}$ at 632 .

135. Jurisdictional Statement of Princeton University at 6, Princeton University v Schmid, 455 US 100

(1982) (No 80-1576).

136. Id at 7-8.

137. Princeton University's Brief at 8-9, Princeton University v Schmid, 455 US 100 (1982) (No 80$1576)$

138. Id at 12. 
brief emphasized in attacking the rationale of the Supreme Court of New Jersey, did not give the government more power to review the implementation of educational policies than if the university had decided to inculcate an ideological orthodoxy. ${ }^{139}$

Though the brief did not focus on the academic freedom of faculty, Princeton did mention in one sentence that the first amendment protects the free speech of professors at public universities from state interference. "Academic freedom," it added in a footnote, "is, of course, especially important to those who teach as well as to the institutions at which they teach, be they public or private." Princeton went on to make clear its own commitment "to the freedom of its faculty and students to pursue knowledge in their own way without interference by governmental or other authority." 140

Princeton's argument to the United States Supreme Court provoked strong objections from many of its own faculty, particularly those with professional interests in constitutional law. ${ }^{141}$ Faculty members urged the administration not to prosecute Schmid ${ }^{142}$ and asserted that the decision to prosecute, rather than involving purely a matter of administrative discretion, posed a policy issue in which the entire university community should be involved. ${ }^{143}$ When these views did not prevail, the faculty focused on its substantive disagreements with the university's position.

Several professors worried that the broad immunity from judicial scrutiny claimed by Princeton would allow any private university unreviewable discretion to restrict the academic freedom of its faculty. Princeton's "distorted" conception of academic freedom, one faculty member argued, posed a far greater threat to intellectual life in universities than either Schmid's activities or the holding of the Supreme Court of New Jersey. Boards of trustees, following Princeton's theory, could simply assert that faculty ideas are "incompatible" with the university's "educational purposes."144 Private universities, other faculty members feared, could invoke institutional academic freedom to preclude judicial review of administrative decisions to fire a professor doing controversial research, to determine the content of courses, to revise the grades assigned by faculty to students, and to revoke tenure without cause. ${ }^{145}$ Professors criticized Princeton for confusing its own institutional autonomy with the faculty's

139. Id at 18 .

140. Id at $9, \mathrm{n} 12$.

141. Andrew Barry, Professors Relieved Over Decision, Daily Princetonian 1 col 3 (January 15, 1982); Letter from Thomas M. Scanlon to William G. Bowen (June 29, 1981); Memorandum from Walter F. Murphy to William G. Bowen (July 8, 1981). Sanford Levinson, an assistant professor in the Department of Politics at Princeton, represented Schmid from his initial arrest through the oral argument in the United States Supreme Court.

142. Barry, Daily Princetonian at 2 col 5 (cited in note 141); Letter from Scanlon to Bowen (cited in note 141 ).

143. Barry, Daily Princetonian at 2 col 5 (cited in note 141)

144. Letter from Scanlon to Bowen (cited in note 141). Professor Scanlon quoted from Princeton's Jurisdictional Statement at 8 (cited in note 135).

145. Princeton Alumni Weekly 15 (December 1, 1981); Walter F. Murphy, Informal Memorandum re Schmid Case (November 23, 1981) ("Murphy Informal Memorandum"). 
academic freedom, and asserted that granting the immunity sought by the university would violate the fundamental principle that no person or institution is above the law. ${ }^{146}$ One professor warned Princeton's president that the best result Princeton could hope for in the Supreme Court would be a decision holding it up as a "laughing stock ... for attacking academic freedom in particular and freedom of discussion in general in the name of private property. Making fun of Princeton-with devastating logic-will become an annual game in which students and faculty elsewhere will delight."147

The AAUP filed an amicus brief with the Supreme Court that reiterated and expanded in legal language many of these faculty views. ${ }^{148}$ It asserted that Princeton's "novel and sweeping claims" 149 combining institutional autonomy and academic freedom, if accepted, would effectively insulate private universities from any government scrutiny. The AAUP emphasized that academic freedom and institutional autonomy are "related but essentially different concepts." 150 Academic freedom, the AAUP insisted, "is a scholar's right to be free of institutional (or governmental) control in professional utterance." 151 Institutional autonomy can be derived from academic freedom in the sense that university autonomy from external control may be necessary to protect its educational functions, including the functions of professors covered by academic freedom. But institutional autonomy also relates to the general control of private property, traditionally protected by the due process clause of the fourteenth amendment, which is no different when the property owner is a university, the corporate owner of a shopping center, or an individual. According to the AAUP, Princeton made a fundamental mistake by failing to distinguish between these two very different forms of institutional autonomy. Only when a university's claims of institutional autonomy relate to its educational functions, the AAUP maintained, is academic freedom at stake. ${ }^{152}$

The AAUP stressed that Princeton's invocation of institutional academic freedom had no connection with its educational mission. Princeton was not trying to protect against an external threat to internal decisions about curriculum or faculty selection, or to the faculty's freedom to teach or do research. Indeed, the Supreme Court of New Jersey indicated an extraordinary willingness to deny state constitutional protection to expressive activity inconsistent in any way with Princeton's professed educational

146. Barry, Daily Princetonian at 2 col 4-5 (cited in note 141); Murphy Informal Memorandum (cited in note 145).

147. Memorandum from Murphy to Bowen (cited in note 141).

148. AAUP's Brief as Amicus Curiae, Princeton University $v$ Schmid, 455 US 100 (1982) (No 801576) ("AAUP Princeton Brief"). Indeed, Professor Thomas M. Scanlon, a professor of philosophy at Princeton who had been involved in the internal university debate over the case (see notes 141-44 and accompanying text), signed the AAUP amicus brief as "of counsel." See also letter from Thomas M. Scanlon to Matthew Finkin (July 22, 1981) (letter to main author of AAUP brief following up telephone conversation and commenting on draft brief).

149. AAUP Princeton Brief at 1 (cited in note 148).

150. Id at 5.

151. Id at 2-3.

152. Id at $2,3,10,18-19$ 
goals. ${ }^{153}$ Princeton, moreover, never provided the slightest clue as to how the material Schmid distributed and sold could interfere with these goals, prompting the AAUP to wonder whether the state court decision "is actually one regulating the university's 'academic functions' at all." 154 Princeton asserted only that any judicial review of the relationship between institutional policies and educational objectives itself violates the institutional academic freedom protected by the first amendment. The AAUP disagreed, observing that the free exercise of religion, also protected by the first amendment, does not prevent the courts from inquiring into the nature and authenticity of religious belief. 155

Not surprisingly, the AAUP emphasized the dangers to faculty members it perceived in Princeton's legal position. Princeton's broad claim of institutional academic freedom, the AAUP warned, would effectively preclude judicial review of institutional decisions "even in cases where the rights or interests of the faculty might be adverse to the institution's administration." Faculty complaints of employment discrimination or of university violations of contractual commitments to academic freedom and tenure, the AAUP observed, relate much more closely to institutional educational policies than did Schmid's distribution and sale of political literature. The institutional academic freedom Princeton invoked against Schmid would apply even more strongly against these faculty complaints. A university could bar judicial scrutiny of faculty contracts merely by claiming that it was following its own educational policies. ${ }^{156}$

In its reply brief, Princeton mostly reiterated its previous position; however, it did respond briefly to some of these faculty concerns. Princeton asserted that the academic freedom protected by the first amendment "is freedom from governmental intrusion into the academic process." It acknowledged that administrators in public universities could engage in prohibited state action by interfering with the individual rights of professors and students. Administrators in private universities, by contrast, are not engaged in state action and thus cannot violate individual first amendment rights even if they, like professors acting against each other, could infringe academic freedom "in a non-constitutional sense." Yet private universities as institutions, Princeton insisted, do have a first amendment right to determine their educational policies free from government interference. ${ }^{157}$ The AAUP, moreover, "grossly" misunderstood Princeton's legal argument against Schmid by suggesting that it would enable the university to use the first amendment as a defense to faculty assertions of contractual violations. Princeton tersely commented that the state police power would permit the

153. Id at 15 .

154. Id at $27 \mathrm{n} 8$.

155. Id at 21 .

156. Id at 28. The letter from Scanlon to Bowen (cited in note 141) makes many of the points discussed in the previous two paragraphs.

157. Princeton University's Reply Brief at 8 n8, Princeton University v Schmid, 455 US 100 (1982) (No 80-1576). 
enforcement of faculty contracts, ${ }^{158}$ but never responded to the AAUP's concern that asserted violations of contractual academic freedom and tenure would implicate university educational policies, and thus under Princeton's argument preclude judicial review, much more directly than the regulations on outsider access applied against Schmid.

A letter from Princeton's university counsel to a faculty member who had objected at length to the university's position in its jurisdictional statement captures better than any legal papers the administration's reaction to faculty concerns. The letter stressed that the legal arguments of the university in Schmid "have nothing to do with the relative powers or rights within an institution between the Trustees and individual faculty members or students," and promised in the university's next brief to avoid any possible implication that Princeton wanted "to diminish the rights of individual faculty members under the concept of academic freedom." Yet the letter also challenged the view that the state is a better ally of faculty academic freedom than the governing boards of private universities. During the McCarthy era, the university counsel claimed, private institutions were substantially more effective than their public counterparts in protecting scholars from state intervention. He added that private boards of trustees, unlike the state, are constrained by different constituencies within the university as well as by a general ethos supporting academic freedom.

The university counsel assured that a Supreme Court victory for Princeton in Schmid would not "directly affect to any degree whatsoever the relationships between the trustees of a private institution and its faculty members." He did concede, however, the possibility that "reasoning by analogy another court down the road would apply rules enunciated in this case to the dissident opinions of faculty and students." Yet a more realistic and directly relevant fear, the counsel warned, was that a defeat for Princeton's position would encourage additional state intervention in university educational decisions in ways that might eventually constrain faculty academic freedom. He observed the historical tendency of increased state power "to homogenization of standards, to fear of the odd case, and to sensitivity to political fashions." The counsel advised that professors, instead of relying on the state, including its courts, to protect their academic freedom, should place their confidence in the diversity of autonomous American universities. ${ }^{159}$

\section{B. University of Pennsylvania v. Equal Employment Opportunity Commission}

By holding that Princeton's new university regulations on access to the campus by outsiders rendered the original dispute moot, the Supreme Court's decision in $S c h m i d{ }^{160}$ produced a severe anticlimax, but it did not end debate on the scope of institutional academic freedom. In University of Pennsylvania $v$.

158. Id at $8 \mathrm{n} 9$.

159. Letter from Thomas $\mathrm{H}$. Wright to Thomas M. Scanlon (July 7, 1981).

160. 455 US 100. 
Equal Employment Opportunity Commission,$^{161}$ the University of Pennsylvania and numerous amici relied on a first amendment claim of institutional academic freedom in asking the Supreme Court to recognize a special privilege against disclosure of confidential peer review materials to the Equal Employment Opportunity Commission ("EEOC") in Title VII cases. The rationale for this special privilege, while made in the context of a Title VII case alleging discrimination based on gender and national origin, would apply as well to a claim that a university impermissibly denied appointment or tenure in violation of a faculty member's academic freedom.

Although various federal circuit courts had held in previous Title VII litigation that constitutional academic freedom requires a qualified privilege against disclosure 162 or a test balancing "academic freedom and educational excellence on the one hand and individual rights to fair consideration on the other,"163 the Third Circuit "expressly declined to limit the EEOC's subpoena authority to accommodate an academic institution's constitutional right to academic freedom." 164 The court acknowledged that such disclosure "would burden the tenure review process and would impact on academic freedom," 165 but it rejected both a qualified privilege and a balancing test because they would allow universities "to hide evidence of discrimination behind a wall of secrecy." 166

The University of Pennsylvania complained that the Third Circuit failed to give any consideration to its first amendment interests in institutional academic freedom. A confidential system of peer review, the university insisted, is essential to determining "who may teach," one of the core components of first amendment academic freedom identified by Frankfurter in Sweezy. ${ }^{167}$ The university readily conceded that the EEOC and individual litigants may in certain circumstances have access to confidential peer review documents in order to further the compelling state interest in eliminating employment discrimination. It objected, however, to the Third Circuit's "automatic disclosure" rule, which gave no weight whatsoever to university interests in academic freedom ${ }^{168}$ and required disclosure of confidential material simply upon the filing of a complaint. ${ }^{169}$ According to the university, the party seeking such material should have to demonstrate specific reasons for disclosure that outweigh the first amendment interests in confidentiality

161. $110 \mathrm{~S} \mathrm{Cl} 577$.

162. EEOC v University of Notre Dame du Lac, 715 F2d 331, 337 (7th Cir 1983).

163. Gray v Board of Higher Educ., City of New York, 692 F2d 901, 907 (2d Cir 1982).

164. EEOC v University of Pennsylvania, 850 F2d 969, 975 (3d Cir 1988), aff'd, 110 S Ct 577 (1990). In reaching this conclusion, the Third Circuit relied on its previous holding in EEOC $v$ Franklin $\mathcal{E}^{\circ}$ Marshall College, 775 F2d 110 (3d Cir 1985).

165. University of Pennsylvania, 850 F2d at 974.

166. Id at 975, quoting from Franklin \& Marshall, $775 \mathrm{~F} 2 \mathrm{~d}$ at 115.

167. University of Pennsylvania Brief at 10-11, 17, 37, University of Pennsylvania v EEOC, $110 \mathrm{~S} \mathrm{Ct}$ 577 (1990) (No 88-493) ("University of Pennsyluania Brief").

168. Id at 12-14.

169. Id at 32,34 . 
shared by universities and the professors who participate in peer review. ${ }^{170}$ "Institutional academic freedom-the university's right to some degree of autonomy-is a necessary corollary," the university maintained, "of the First Amendment rights of the individual university professor."171 As at Princeton, a number of faculty members opposed the University's legal position. ${ }^{172}$

The AAUP, while appearing as a nonaligned amicus and specifically disclaiming any position on whether the university should be required to disclose the confidential peer review materials at issue, challenged the Third Circuit's legal standard as constitutionally inadequate. ${ }^{173}$ The AAUP had anticipated this issue in Schmid, where it cited unrestrained discovery in Title VII litigation as an example of government regulation that, unlike the holding allowing Schmid access to Princeton's campus, could impinge upon a university's academic freedom. ${ }^{174}$ Presented with this precise issue in University of Pennsylvania, the AAUP characterized the Third Circuit's holding as containing the "startling proposition" that the first amendment protection for academic freedom "in no way limits the subpoena authority of a government agency."'175

The AAUP saw a precise analogy between EEOC investigations of tenure files and the investigations into the contents of university lectures conducted by legislative committees concerned about communist subversion during the McCarthy era. "The single most consistent and most rigorous application of this Court's academic freedom decisions," the AAUP stressed citing Sweezy, "has related directly to investigative claims pressed by government itself."176 As in the earlier cases, the AAUP urged, the Court should not immunize universities from government scrutiny, but should balance the competing investigative and academic interests. The AAUP also took pains to note that University of Pennsylvania did not pose any tension between the academic

170. Id at 45-46, 49. The University of Pennsylvania conceded that the university should provide confidential letters on which the tenure decision is based to the EEOC and a statement of reasons for the decision to the complainant or the EEOC. Substantial evidence of discrimination uncovered from nonconfidential information, the university added, can justify access to otherwise confidential peer review materials. Id at 46-47. This approach closely resembles the one advocated in AAUP, $A$ Preliminary Statement on Judicially Compelled Disclosure in the Nonrenewal of Faculty Appointments, 67 Academe 27 (February-March 1981) (attached as appendix A to AAUP's Brief as Amicus Curiae, University of Pennsylvania v EEOC, $110 \mathrm{~S} \mathrm{Ct} 577$ (1990) (No 88-493) ("AAUP University of Pennsylvania Brief"').

171. University of Pennsylvania Brief at 16 (cited in note 167).

172. The Association of Women Faculty and Administrators of the University of Pennsylvania participated in a brief amici curiae in support of the EEOC. In its statement of interest, the association maintained that its members "know from concrete experience-including the denial of tenure to Professor Rosalie Tung, which gave rise to the present proceeding-that the task of eradicating the effects of gender-based discrimination is far more difficult, and the need to retain unimpaired the ability of the Equal Employment Opportunity Commission to carry out its mission far more critical, than is suggested by petitioner [University of Pennsylvania] here." NOW Legal Defense and Education Fund and Rosalie Tung's Brief as Amici Curiae at 29, University of Pennsylvania $v E E O C, 110$ S Ct 577 (1990) (No 88-493).

173. AAUP University of Pennsylvania Brief at $3 \mathrm{n} 6$ (cited in note 170).

174. AAUP Princeton Brief at 25 (cited in note 148).

175. AAUP University of Pennsylvania Brief at 7 (cited in note 170).

176. Id at 5. See also id at 12 . 
freedom of the university and the academic freedom of the faculty. Without citing the 1915 Declaration, the AAUP stressed that by giving the faculty primary responsibility for the tenure decision, the university was following a traditional and well-justified academic policy that merited first amendment protection. ${ }^{177}$

The government's brief flatly denied that the Third Circuit's holding interfered with academic freedom. While noting that prior Supreme Court decisions had not clarified the definition of constitutional academic freedom, the government assumed that it included the university's choice of professors. Yet the government emphasized that Sweezy itself extended this freedom only to decisions made "on academic grounds." University employment decisions based on the kinds of invidious discrimination prohibited by Title VII, the government suggested, are not made "on academic grounds" and thus are not entitled to constitutional protection. Indeed, the government asserted that individual faculty members have a countervailing academic freedom interest in being evaluated on the basis of their professional performance. EEOC investigations of peer review decisions determine only whether these decisions are based on academic considerations or on discriminatory ones, and thereby reinforce rather than undermine the appropriate tradition of judicial deference to university decision-making. ${ }^{178}$ The government observed as well that when removing the exemption of universities from Title VII in 1972, Congress rejected arguments that EEOC investigations would violate academic freedom by intruding on the selection and promotion of faculty. ${ }^{179}$

The Supreme Court unanimously rejected the University of Pennsylvania's first amendment claim and essentially accepted the government's position. Cases such as Sweezy and Keyishian, the Court observed, involved direct governmental restrictions on the content of speech and on the right of the university to determine who may teach. Unlike Keyishian, where the government attempted to substitute its employment criteria for those of the university, the EEOC left the University of Pennsylvania free to select and apply its own standards as long as they did not violate the proscriptions against employment discrimination in Title VII. The Court recognized that the "precise contours" 180 of its prior academic freedom decisions remained undefined. Yet it considered itself fortunate in not having to provide

177. Id at $10 \mathrm{n9}$. See also Brief of Princeton University, Brown University, Harvard University, and Yale University as Amici Curiae, University of Pennsylvania v EEOC, $110 \mathrm{~S}$ Ct 577 (1990) (No 88493). Many within the AAUP opposed its policy of limiting disclosure of peer review materials and objected to the official position in the AAUP brief. See Memorandum from Mary Gray, Chair of Committee W of AAUP to Carol Stern, et al, Committee on Litigation (May 3, 1989) (conveying unanimous recommendation of AAUP committee on the status of women that AAUP should not file brief based on its existing Preliminary Statement). See also AAUP, University of Pennsylvania $v$ EEOC and the Status of Peer Review: A Symposium, 76 Academe 31 (May-June 1990) (various reactions of professors and a college president to Supreme Court decision).

178. Respondent's Brief at 26-29, 26-27 n19, University of Pennsylvania v EEOC, $110 \mathrm{~S} \mathrm{Ct} 577$ (1990) (No 88-493).

179. Id at 12-13.

180. $110 \mathrm{~S} \mathrm{Ct}$ at 586 . 

private than at public universities, but it did recognize this issue in University of Pennsylvania, its only major decision involving an academic freedom claim by a private university. ${ }^{188}$ The Court noted that attempts by government to regulate the selection of faculty or otherwise influence academic speech at private universities would create obvious first amendment problems. Analogous attempts at public universities, the Court added without further explanation, would present complicated first amendment issues because the government would be both the regulator and the speaker. ${ }^{189}$

Earlier Supreme Court decisions, however, do suggest first amendment constraints on the institutional academic freedom of public universities that may not apply to their private counterparts. The Court in Sweezy and Keyishian, cases that arose at public universities, emphasized the value of critical inquiry in universities to democracy and civilization while justifying first amendment protection of academic freedom. First amendment academic freedom, the Court stressed, requires a "robust exchange of ideas" in universities and precludes a "pall of orthodoxy" or a "straight jacket" on intellectual life. The search for truth in universities must be open to a "multitude" of views and must not be subject to the "authoritarian selection" of "absolutes."'190 Even while acknowledging greater discretion for state inculcation of societal values in the high school setting than in universities, the Court has warned that public schools must be careful not to "eliminate all diversity of thought."'191

Recent scholarly exploration of the democratic functions of universities supports this first amendment analysis. Professor Amy Gutmann has argued convincingly that universities serve democracy as institutional sanctuaries against repression of unpopular ideas, an analysis that recalls the emphasis in the 1915 Declaration on the university's role as an "inviolable refuge" 192 for scholarly views that challenge prevailing public opinion and government policy. The academic freedom of universities from state intrusion, Gutmann asserts, protects debate about politically relevant ideas from the potential tyranny of democratic majorities or coalitions of minorities. In universities protected by academic freedom, in possible contrast to legislatures or to

188. $110 \mathrm{~S} \mathrm{Ct}$ 577. The Supreme Court's reliance on Princeton's newly passed regulations mooted the important academic freedom issues presented in Schmid, 455 US 100 . See text accompanying note 129 .

189. $110 \mathrm{~S} \mathrm{Ct}$ at 586-87, n6, citing Yudof, When Government Speaks (cited in note 24). The Court's explicit recognition of academic freedom cases at public universities refutes Dean Yudof's earlier prediction that the ascription of first amendment academic freedom to a public university by Justice Powell in Bakke would not be followed in subsequent cases. Yudof, 32 Loyola L Rev at 855-56 (cited in note 24). Indeed, Powell's opinion was not a "revisionist view of institutional academic freedom" with "revolutionary" implications. Id at 855. Sweezy and Keyishian, the initial Supreme Court decisions constitutionalizing academic freedom, arose at public universities, as did later decisions reiterating first amendment academic freedom such as Widmar and Regents of University of Michigan $v$ Ewing, 474 US 214 (1985).

190. These quotations are from Sweezy, 354 US at 250, and Keyishian, 385 US at 603. See notes 41-44 and accompanying text.

191. Pico, 457 US at 879 (Blackmun concurring). See also Bethel School Dist., 478 US at 681.

192. 1915 Declaration at 167; Appendix $A$ at 400 (cited in note 6). 
general political debate, ideas are evaluated on their scholarly merits, not their political popularity. ${ }^{193}$ Unpopular ideas kept alive in universities remain available to the broader society.

The democratic functions of universities, however, may have more salience in public institutions, where, as the Supreme Court has observed, the state is the speaker as well as the regulator. Public universities, themselves bound by the first amendment in their relationships with faculty and students, may have less discretion than private universities in selecting educational purposes that arguably deviate from democratic values. The same educational choices that might violate the first amendment obligations of public universities to diversity of thought might be protected by the first amendment academic freedom of private universities against state intrusion. For example, the private "proprietary institutions" identified in the 1915 Declaration, formed to advocate a protective tariff or socialism, might have institutional academic freedom from state attempts to require more diversity of thought, even though the first amendment might preclude the state from establishing such institutions. Similarly, a private university might have academic freedom to declare itself an "ivory tower" committed to the world of ideas uncontaminated by influences from the outside world, and therefore might be permitted to impose absolute restrictions on public access to the campus that might violate the first amendment if adopted by a public university. If Princeton, rather than inviting public use of its campus, had declared itself such an ivory tower, the Supreme Court of New Jersey might have deferred to this choice of educational policy. ${ }^{194}$ However, Rutgers, the major state university in New Jersey, might not have similar discretion in choosing an educational policy that precludes public access.

Arguably, this first amendment combination of limiting state interference with the discretion of private universities while constraining their public counterparts itself promotes democratic values. Private universities may choose to establish educational policies that deviate from democratic values in ways forbidden to state institutions. The resulting pluralism within the academic world, however, may provide more tolerance for diverse and

193. Amy Gutmann, Democratic Education 174, 179 (Princelon, 1987). See also Amy Gutmann, /s Freedom Academic?: The Relative Autonomy of Universities in a Liberal Democracy in J. Roland Pennock \& John W. Chapman, eds, Nomos 25: Liberal Democracy 257, 271 (New York Univ Press, 1983). Professor Byrne makes a similar point to support first amendment academic freedom for universities. Independent and expert critical thought in universities, he maintains, is "crucial for society as a whole because it provides a standard by which to gauge how trivial, debased, and false is much public discussion of affairs." Byrne, 99 Yale L J at 334 (cited in note 1).

194. See Schmid, 84 NJ at 564-65, 423 A2d at 631 . But see Sanford Levinson, Princeton v. Free Speech: A Post Mortem in Craig Kaplan \& Ellen Schrecker, eds, Regulating the Intellectuals 200 (Praeger, 1983) ("republican form of government" guaranteed by Article IV of U.S. Constitution requires "voting citizens of the United States freedom to interact with their fellow citizens-whether students or outsiders-in conversation about the great issues of the polity"). See also Gutmann, Nomos 25: Liberal Democracy at 267-68 (cited in note 193) (though "secluded residential college dedicated to religious indoctrination" has a better argument than Princeton for restricting access to campus by local political candidates, the democratic "right of political communication" may outweigh the "right of religious education"). 
unpopular views than a rule that would subject all universities to the commitment to diversity of thought that the first amendment imposes on public ones. ${ }^{195}$

Private universities may have purposes unrelated to education that similarly allow them to deviate from first amendment limitations on public universities. A university affiliated with a religious denomination, another example in the 1915 Declaration of a proprietary institution, may make institutional choices for religious rather than educational reasons, and those choices may be protected by the free exercise clause of the first amendment. A Catholic university could require its teachers to adhere to the Church's theological position on artificial contraception, ${ }^{196}$ and a fundamentalist

195. Dean Yudof emphasizes that the first amendment can foster pluralism by protecting private speech and by limiting government expression. He prefers the first approach because limiting government expression presents "dangers of judicial overreaching" and "remedial quandaries." Yudof, When Government Speaks at 200 (cited in note 24). "Any judicial decision protecting the right of private individuals, groups, or organizations to speak," he reasons, "strengthens their ability to communicate and increases their potential to counter government messages." Id at 201. Applying this general principle, he maintains that "institutional academic freedom protects the private school from an overreaching government authority," and "tends to diminish the ability of government to suppress competing ideas and ideologies." Yudof, 32 Loyola L Rev at 852-53 (cited in note 24).

Dean Yudof, who finds prior decisions protecting individual academic freedom "difficult to justify," Yudof, When Government Speaks at 215 (cited in note 24), would interpret them as part of his general approach to government speech. He suggests that "the focus should be not on the constitutional entitlements of the teacher per se, . . . but on the place of the teacher in the system of government expression." Id at 216 . He indicates that first amendment protection for individual academic freedom, though unsupported by arguments derived from personal autonomy, Yudof, 32 Loyola L Rev at 838 (cited in note 24), can be justified by the fact that "the autonomy of the classroom teacher contributes to a diminution of the power of government to work its communication will" and thereby introduces "a sort of pluralism into the school environment." Yudof, When Government Speaks at 216 (cited in note 24). Yet Dean Yudof resists constitutional protection for the academic freedom of public institutions. Yudof, 32 Loyola L Rev at 855-56 (cited in note 24). See note 189 .

Professor Gutmann might impose greater constraints than Dean Yudof on private universities. She rejects the "corporate pluralist" argument, which is "corporatist in ascribing a right to autonomy to private institutions, and pluralist in proclaiming the value of diversity among those institutions." Gutmann, Nomos 25: Liberal Democracy at 261-62 (cited in note 193). The need for universities to serve as an "institutional sanctuary for the process of free intellectual inquiry essential to democratic politics," she maintains, applies to both private and public institutions. Id at 263. A democratic state should promote liberal over nonliberal private universities because it depends "upon the free development and dissemination of ideas to which liberal universities are uniquely dedicated as social institutions." Id at 264. Yet Gutmann acknowledges that "a university with explicitly nonliberal religious purposes may need to restrict the academic freedom of its faculty as a means of furthering its purposes." Apparently, Gutmann favors greater discretion for private universities than for public ones, limited by state determinations that private "purposes and policies" are "incompatible with the effective exercise of other basic rights supporting citizenship in a democratic society." Id at 263. See also Levinson, Princeton $v$. Free Speech at 200-02 (cited in note 194) (constitutional guarantee of "republican form of government" limits discretion of private universities).

Dean Yudof, though perhaps favoring more discretion for private universities than Professors Gutmann or Levinson, agrees that the state can impose limits on institutional autonomy. "In each case," he writes, "the compelling nature of the public policy and the limits of tolerance must balance against the specific infringement on institutional autonomy. Not surprisingly, principled results are frequently illusive." Yudof, 32 Loyola L Rev at 853-54 (cited in note 24). See text accompanying notes 201-08 (discussing tensions between state and university interests).

196. See Curran v Catholic University of America, No 1562-87 (DC Superior Ct, filed February 28, 1989) (unpublished opinion on file with court) (rejecting claim that university breached professor's contractual right to academic freedom). "On some issues," the court reasoned, "the conflict between the University's commitment to academic freedom and its unwavering fealty to the Holy See 
Protestant university could require the exclusive teaching of "creation science" even if this theory has no respectable scholarly or pedagogical basis. ${ }^{197}$

The freedom of association protected by the first amendment and basic property rights provide additional constitutional protections for the institutional choices of private universities. ${ }^{198}$ A private university might decide to limit access by outsiders, not for the educational purpose of creating an ivory tower, but simply to keep its property clean. ${ }^{199}$ Yet as the AAUP maintained in Schmid, a private university cannot appropriately base its claims of autonomy on institutional academic freedom unless they can be justified on educational grounds. ${ }^{200}$

Even when it is legitimately invoked, institutional academic freedom at both private and public universities may compete with and at times succumb to other state interests. For example, the fourteenth amendment imposes barriers to university affirmative action plans, ${ }^{201}$ just as government commitments to affirmative action could jeopardize university interests in

is direct and unavoidable. On such issues, the University may choose for itself on which side of that conflict it wants to come down, and nothing in its contract with Professor Curran or any other faculty member promises that it will always come down on the side of academic freedom." Id at 34. But see Academic Freedom and Tenure: The Catholic University of America, 75 Academe 27, 37 (September-October 1989) (AAUP investigating committee finds that University violated Curran's academic freedom by forcing him to relinquish all teaching of Catholic theology). Compare Charles E. Curran, Academic Freedom and Catholic Universities, 66 Tex L Rev 1441 (1988) (arguing for greater academic freedom at Catholic universities than official Church documents and legislation allow) with Douglas Laycock \& Susan E. Waelbroeck, Academic Freedom and the Free Exercise of Religion, 66 Tex L Rev 1455 (1988) (arguing that free exercise clause precludes courts from determining extent of academic freedom at Catholic universities). See also Michael W. McConnell, Academic Freedom in Religious Colleges and Universities, 53 L \& Contemp Probs 303 (Summer, 1990).

197. Compare Edwards $v$ Aguillard, 482 US 578 (1987) (law forbidding teaching of evolution in public schools unless "creation science" is also taught violates establishment clause of first amendment).

198. Dean Yudof recognizes freedom of association as "an immensely reasonable gloss to place on freedom of expression once one recognizes the desirability of countering the communications power of governments in a democracy." Yudof, When Government Speaks at 258 (cited in note 24). See id at 255-58.

199. Compare NLRB v Babcock $\&$ Wilcox Co., 351 US 105, 107, 112 (1956) (employer interest in controlling property and preventing litter justify refusal to allow distribution of literature by union organizers in company parking lot) with Schneider v State, 308 US 141, 162 (1939) (city ordinance prohibiting distribution of handbills to pedestrians on public streets violates first amendment; legislative purpose of keeping streets clean is "insufficient to justify an ordinance which prohibits a person rightfully on a public street from handing literature to one willing to receive it").

200. See text accompanying notes 152-55. Professor Finkin, the primary author of the AAUP brief in Schmid, reiterated this point in a subsequent article. Professor Finkin finds "particularly perverse" the application of the term "academic freedom" to institutional autonomy based on "an excresence of property rights . . unrelated to the maintainence of conditions of academic freedom within the institution." Finkin, 61 Tex L Rev at 839 (cited in note 24). Byrne, 99 Yale L J at 321-22 (cited in note 1), agrees with Finkin. See also Gutmann, Nomos 25: Liberal Democracy at 276 (cited in note 193) ("academic freedom as an institutional right ... is not so broad as to permit any university to defend itself against those governmental regulations that are compatible with, or instrumental to achieving, a university's self-proclaimed educational purposes").

201. Bakke, 438 US 265. 
selecting faculty and students. ${ }^{202}$ First amendment public forum analysis can limit the discretion of state universities to restrict even for legitimate educational purposes the use of their facilities unless those purposes are "compelling." 203 State constitutions that give individuals a right to speak on private property must be balanced against the interests of universities in determining their own purposes and policies. ${ }^{204}$ Threats to national security or public health may justify state restrictions on university research. ${ }^{205}$ Genuine religious beliefs may have to give way to competing public interests. $^{206}$ It may be that most government regulations, such as accreditation requirements and prohibitions against racial discrimination, rarely interfere with any legitimate interests of universities. ${ }^{207}$ But the interests of universities can conflict with those of governments and citizens, and close questions may arise when these conflicting interests are both strong. ${ }^{208}$

\section{B. Does Institutional Academic Freedom Protect State Universities from Other Branches of Government?}

In contrast to private universities, state universities may be constrained by both the first amendment and the state that creates and funds them. Despite judicial reiteration that institutional academic freedom encompasses the four essential freedoms of a university identified in Sweezy, substantial ambiguity exists regarding the scope of those freedoms. State legislatures often fund community colleges as well as four-year colleges, establish agricultural colleges as well as liberal arts universities, and determine which state universities may offer graduate degrees in various subjects. Insufficient legislative appropriations can lead to the elimination of existing faculty positions, ${ }^{209}$ and legislatures can refuse to provide any funding for universities. These legislative decisions clearly limit the freedom of state colleges and universities to determine "who may teach," "what may be

202. See Byrne, 99 Yale $\mathrm{L} \mathrm{J}$ at $\mathbf{2 8 2 - 8 3}$ (cited in note 1) (observing legitimate tension between some affirmative action plans that may be "derogations from accepted notions of professional competence for political reasons" and traditional notions of academic freedom).

203. See, for example, Widmar, 454 US 263, 269-70, 276-77.

204. See, for example, Schmid, $84 \mathrm{NJ}$ at $560,423 \mathrm{~A} 2 \mathrm{~d}$ at 628

205. See Rabban, 66 Tex L Rev at 1419 (cited in note 19).

206. See Bob Jones University v United States, 461 US 574, 602-04 (1983) (denial of student admission based on genuine university belief that Bible forbids interracial dating and marriage outweighed by fundamental government interest in eliminating racial discrimination).

207. See, for example, Gutmann, Democratic Education at 179-80 (cited in note 193); Finkin, 61 Tex L Rev at 855-56 (cited in note 24); Gutmann, Nomos 25: Liberal Democracy at 276 (cited in note 193); Yudof, 32 Loyola L Rev at 853-54 (cited in note 24). But see Dallin H. Oaks, A Private University Looks at Government Regulation, $4 \mathrm{~J}$ Coll \& Univ L 1, 3.4 (1976) (claiming most federal regulation of universities constitutes interference in management of educational functions that violates academic freedom).

208. See Gutmann, Democratic Education at 187 (cited in note 193); Gutmann, Nomos 25: Liberal Democracy at 266, 282-83 (cited in note 193).

209. See, for example, Johnson v Board of Regents of University of Wisconsin System, 377 F Supp 227 (WD Wis 1974), aff'd, 510 F2d 975 (9th Cir 1975); Levitt v Board of Trustees of Nebraska State Colleges, 376 F Supp 945 (D Neb 1974). 
taught," and "who may be admitted to study," but no one has ever argued that they violate a public university's institutional academic freedom.

In some states, constitutional provisions establish state university systems as a separate branch of government. State courts have interpreted these provisions to preclude legislative attempts to fix the location of academic departments and the percentage of out-of-state students. ${ }^{210}$ But in the majority of states, in which no constitutional separation of powers exists to protect the state university, it seems difficult to argue that the first amendment poses a bar to such legislative decisions. ${ }^{211}$ Legislative attempts to dictate to private universities the composition of their student bodies or their general educational purposes, by contrast, would surely implicate their institutional academic freedom.

As decisions like Sweezy and Keyishian make clear, however, first amendment academic freedom imposes some limitations on legislative and administrative regulation of public universities. In Sweezy, the New Hampshire legislature violated the first amendment academic freedom of a university lecturer and of the "academic community" 212 by establishing a program of legislative investigations into subversive activities that included inquiries into the contents of a lecture at the University of New Hampshire. In Keyishian, a combination of vague statutes and administrative regulations violated first amendment academic freedom by subjecting professors to possible dismissal for teaching the principles of Marxism. ${ }^{213}$

The solicitor general explicitly distinguished Sweezy and Keyishian during oral argument in University of Pennsylvania, stressing that the EEOC's inquiry into the tenure process had "nothing to do with the world of ideas" and did not touch on classroom speech. ${ }^{214}$ The Supreme Court's decision echoed this theme, and reinforced Sweezy and Keyishian by contrasting the legislative restrictions on the content of speech and on the university's selection of professors in those cases with the EEOC's investigation into whether the university had violated federal prohibitions against employment discrimination. The Court made a special point of emphasizing that it would

210. Regents of the University of Michigan $v$ State, 47 Mich App 23, 208 NW2d 871 (1973) dismissed as moot, 395 Mich 52, 235 NW2d 1 (1975) (unconstitutional for legislature to fix percentage of outof-state students); Sterling $v$ Regents of the University of Michigan, 110 Mich 369, 68 NW 253 (1896) (unconstitutional for legislature to determine location of departments). See Byrne, 99 Yale L J at 327-28 (cited in note 1).

211. Professor Byrne maintains that state constitutional autonomy for universities as a separate branch of government provides a "legal source for constitutional academic freedom." Byrne, 99 Yale $\mathbf{L} \mathrm{J}$ at 327 (cited in note 1). I find this argument unpersuasive. The fact that a few states have constitutionally provided for university autonomy does not suggest that similar protection should be read into the first amendment. Byrne cites only nine states that have explicitly provided constitutional autonomy for universities, though he adds that in an unidentified number of other states "courts have been willing to interpret often ambiguous constitutional language as imposing limitations on the legislature." Id at 327 n303.

212. Sweezy, 354 US at 245.

213. Keyishian, 385 US at 600.

214. Official Transcript Proceedings Before the Supreme Court of the United States at 43 , University of Pennsylvania v EEOC (Nov 7, 1989) (No 88-493) ("University of Pennsylvania Oral Argumen '"). 
not "retreat" from its longstanding respect for the right of universities to make their own academic decisions. ${ }^{215}$

Some legislative and administrative controls over state universities seem clearly permissible, while others just as clearly violate the institutional academic freedom constitutionalized by the Supreme Court. Unfortunately, prior cases offer scant guidance in determining exactly when state actions violate the constitutional rights of institutions the state itself has created. As the earlier discussion of institutional context indicates, ${ }^{216}$ however, some analytical hints have appeared in recent cases involving a variety of state institutions, including universities.

Federal Communications Commission v. League of Women Voters 217 provides the most clues about first amendment constraints on government regulation of its own institutions. The same congressional legislation that created and funded the Corporation for Public Broadcasting forbade editorializing by noncommercial educational broadcasting stations receiving grants from the corporation. Many of these stations are publicly owned and financed.218 While recognizing that this congressional ban on editorializing was designed to serve the public's interest in receiving balanced coverage,${ }^{219}$ the Court held that it violated "important journalistic freedoms which the first amendment jealously protects." 220

Because "broadcasters are engaged in a vital and independent form of communicative activity," the Court reasoned, "the first amendment must inform and give shape to the manner in which Congress exercises its regulatory power in this area." The Court concluded that the legitimate public interest in balanced coverage depends largely on "the editorial initiative and judgment of broadcasters who bear the public trust.'"221 Alternative regulatory means, the Court observed, could serve the public interest in balanced coverage without jeopardizing "the 'journalistic freedom' of noncommercial broadcasters." 222 This recognition of the first amendment value of "journalistic freedom" parallels the Court's emphasis on the first amendment value of "academic freedom" in Sweezy and Keyishian.

Significantly, even the dissenters recognized that broadcasters have first amendment rights. They observed that Congress could not condition funding for public stations on the broadcasters' agreement to avoid controversial subjects $^{223}$ or to promote particular viewpoints. ${ }^{224}$ Justice Stevens stressed in dissent that the ban on editorializing was enacted "to avoid the risk that some

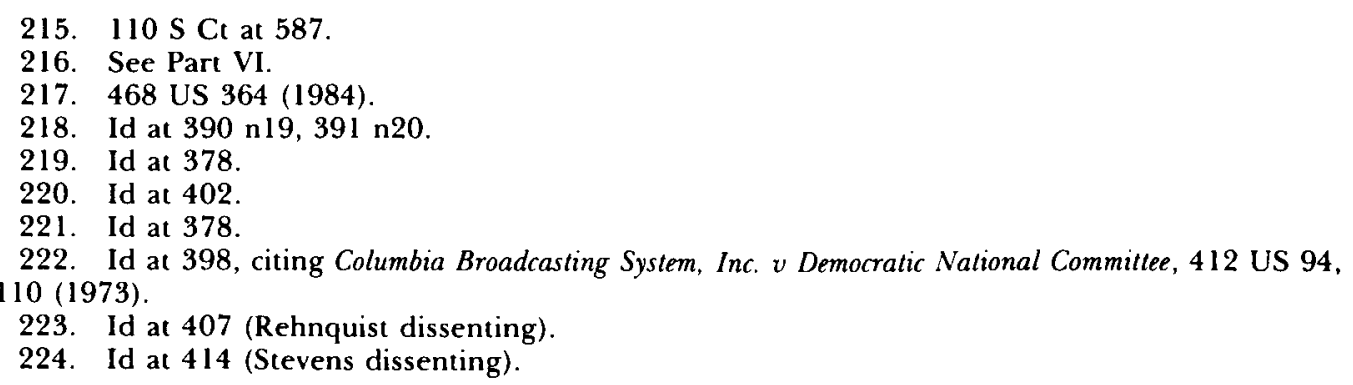


speakers will be rewarded or penalized for saying things that appealed to-or are offensive to-the sovereign."225

In distinguishing state-created institutions from public forums, ${ }^{226}$ the Court has underlined both the general first amendment prohibition against viewpoint discrimination and the principle that certain institutions have traditional and broadly accepted expressive functions the state must accept when it creates them. Dissenting in Southeastern Promotions, Limited v. Conrad, ${ }^{227}$ Justice Rehnquist foreshadowed subsequent majority decisions when he criticized the Court for applying public forum doctrine to the production decisions of a community-owned theater. The majority overturned on first amendment procedural grounds the rejection by the theater directors of an application to present the controversial rock musical "Hair," which contained group nudity and simulated sex. Rehnquist conceded in dissent that a municipal theater, unlike a private one, cannot "judge on a content basis alone" which plays to perform. ${ }^{228}$ He noted, for example, that a municipal auditorium could not forbid a production of "Hair" based on opposition to the musical's political and social views while allowing performances of "equally graphic productions" whose ideas did not offend. ${ }^{229}$ Yet he added that the element of a municipal theater 'which is 'theater' ought to be accorded some constitutional recognition along with that element of it which is 'municipal." "290 At the very least, the directors of the municipal theater should have some discretion to decide what performances to book. Surely, Rehnquist suggested, a municipal theater should be able to devote an entire season to Shakespeare rather than to accept all bookings in order of application date until no openings are left. ${ }^{231}$

The Court majority's subsequent recognition in Widmar $v$. Vincent that the educational mission of a university distinguishes it "in significant respects from public forums such as streets or parks or even municipal theaters"232 seems to accept Justice Rehnquist's distinction in Southeastern Promotions between public forums and state-created institutions. The Widmar majority's reiteration of the "four essential freedoms" quoted by Frankfurter in Sweezy ${ }^{233}$ also reinforced Rehnquist's indication that the functions of state institutions may require first amendment protection for content-based decisions made within them. Justice Stevens's concurring opinion elaborated by maintaining that the institutional academic freedom of public universities should allow them to make educationally related appointment and curricular

225. Id.

226. See generally Post, 34 UCLA L Rev 1713 (cited in note 67). Professor Post distinguishes between government management of its own institutions for instrumental purposes and its regulation of public forums.

227. 420 US 546 (1975).

228. Id at 573 (Rehnquist dissenting).

229. Id at $572 \mathrm{n} 2$.

230. Id at 573-74.

231. Id at $571-73$.

232. 454 US at $268 \mathrm{n} 5$.

233. Id at 276. 
decisions based on the content of speech. ${ }^{234}$ Lower-court decisions have underlined this approach, recognizing that the expressive functions of state university newspapers and public broadcasting stations justify first amendment protection for their editorial discretion. ${ }^{235}$

The functions of some state institutions might be contested. For example, the differing conclusions of Justices Brennan and Rehnquist in Pico ${ }^{236}$ derived largely from their disagreement about the functions of a school library. Both justices agreed that the state cannot force its own institutions to suppress ideas based merely on disagreement with their content, but that it can consider the institution's functions in regulating the content of speech. Justice Brennan stressed the "unique role of the school library" in providing "wholly optional" opportunities for "self-education" and "individual enrichment." He distinguished "the regime of voluntary inquiry" in the school library from the "compulsory environment of the classroom."237 Justice Rehnquist dismissed this characterization of the role of a school library as Brennan's own unsupported "creation." Criticizing Brennan for relying on precedents dealing with public libraries and universities, Rehnquist concluded that Brennan's "reasoning misapprehends the function of libraries in our public school system." In contrast to "university or public libraries, elementary and secondary school libraries are not designed for freewheeling inquiry; they are tailored, as the public school curriculum is tailored, to the teaching of basic skills and ideas." Indeed, the school library is "the one public institution which, by its very nature, is a place for the selective conveyance of ideas."'238

It is extremely revealing that the dispute between Justices Brennan and Rehnquist over the function of a school library provoked Justice Rehnquist to affirm his understanding of university libraries as places devoted to "freewheeling inquiry." Quite clearly, Rehnquist would not allow a university

234. Id at 277-78. See text accompanying notes 110, 124-25 (discussing Stevens's concurrence).

235. See, for example, Schneider v Indian River Community College Foundation, 875 F2d 1537, 1541 (11th Cir 1989) (college trustees, as licensees of public radio station, have first amendment right to exercise programming discretion; "the degree of control which can be exercised consistently with the First Amendment depends on the mission of the communicative activity being controlled"); Estiverne v Louisiana State Bar Ass'n, 863 F2d 371, 381-82 (5th Cir 1989) (state bar journal not public forum; editors have "editorial discretion" to refuse to publish letter based on the journal's purposes but not on the letter's viewpoint); Muir v Alabama Educational Television Comm'n, 688 F2d 1033, 1041, 1044 (5th Cir 1982) (public television station not public forum; "First Amendment does not preclude the government from exercising editorial control over its own medium of expression"); id at 1052 (Rubin concurring) ("state's discretion is confined by the functions it may perform as a broadcast licensee, and the purpose to which it has dedicated its license"); Joyner $v$ Whiting, 477 F2d 456, 460 (4th $\mathrm{Cir} 1973$ ) (college cannot suppress student newspaper "because college officials dislike its editorial content"); Bazaar v Fortune, 476 F2d 570, 574 (5th Cir 1973) (state university cannot “" support a campus newspaper and then try to restrict arbitrarily what it may publish, even if only to require that material be submitted to a faculty board to determine whether it complies with 'responsible freedom of the press' "), citing $A C L U v$ Radford College, 315 F Supp 893, 896-97 (WD Va 1970).

236. 437 US 853 .

237. Id at 869 .

238. Id at 914-15 (Rehnquist dissenting). 
or a state legislature to remove from a university library the books he would have allowed the school board to remove from school libraries in Pico.

Regulation of lawyers employed by the state similarly illustrates that appropriate restrictions on speech in one kind of state institution may be unconstitutional in others. The solicitor general, whose function is to support government positions before the Supreme Court, should be able to condition continued employment of staff attorneys on their advocacy of legal arguments that conform to government policy. By contrast, a state university, whose function is to promote critical inquiry in the search for knowledge, should not be able to condition continued employment of law professors on their advocacy of legal arguments favored by the dean or the state legislature. ${ }^{239}$ Yet legislation requiring the teaching in law school of "practical" courses designed to prepare lawyers for practice in the state may be justified as furthering a valid institutional purpose.

The reasoning of cases such as Federal Communications Commission, Widmar, and Pico also suggests that a state cannot simply announce its departure from traditionally understood institutional functions. ${ }^{240}$ A state could not, for example, create a university devoted exclusively to the inculcation of societal values rather than to critical inquiry. Pico indicates that the first amendment requires even a secondary school to allow "some limits" on its inculcative functions, and that what may be a permissible mix of inculcation and

239. I am grateful to David Anderson for suggesting this comparison.

240. Dean Yudof's analysis of the delegation of authority by political branches of government to institutions exercising specialized functions imposes substantial restrictions on government interference in those institutions. His analysis, however, does not preclude the government from restructuring or changing the functions of its own institutions. See Yudof, When Government Speaks at 135-38, 240-45 (cited in note 24); Mark G. Yudof, Library Book Selection and the Public Schools: The Quest for the Archimedean Point, 59 Ind L J 527, 553-59 (1984).

Dean Yudof observes that elected government officials frequently delegate specialized government functions to state institutions such as schools and universities, hospitals, student newspapers, public television stations, and libraries. Considerations of expertise and efficiency often lie behind delegations to professionals within state agencies. Yudof, When Government Speaks at 136 , 243 (cited in note 24). These delegations, as Yudof observes with approval, often have the welcome benefits of serving as "a bulwark against the centralized orchestration of a publicly established orthodoxy," Yudof, 59 Ind L J at 553 (cited in this note), and of preventing "political interference" in state institutions. Yudof, When Government Speaks at 136 (cited in note 24). Yudof would even recognize de facto delegations when higher government officials have no policy on institutional functions. Yudof, 59 Ind $\mathrm{L}$ J at 555 (cited in this note). Ad hoc revocations of prior voluntary delegations for the purpose of censoring particular ideas, Yudof maintains, should be considered first amendment violations. Yudof, When Government Speaks at 243 (cited in note 24).

Although Dean Yudof recognizes that delegations of government authority promote first amendment interests in preventing "government established orthodoxy" and "ideological indoctrination," he would not interpret the first amendment to require delegation. Yudof, 59 Ind $\mathrm{L} J$ at 554 (cited in this note). He concludes, based on the general theory of delegation, that "government is not locked into existing institutional arrangements, and barring a restructuring effort growing out of an attempt to censor, government agencies are free to undo their delegations." Yudof, When Government Speaks at 244 (cited in note 24). For reasons I discuss throughout the text of this section, I disagree with Dean Yudof and consider the first amendment a constraint on state regulation of the expressive functions of its own institutions. 
"diversity of thought" in secondary schools may be unconstitutional in colleges and universities, which have different functions. ${ }^{241}$

Although institutional functions may not be as fixed as the functions of traditional public forums, analogies to public forum doctrine are instructive. A state could not simply announce that a park or a street is no longer a public forum. Historic institutional functions may not have the "immemorial" tradition the Court has cited in declaring streets and parks public forums, ${ }^{242}$ but some institutional traditions are sufficiently strong and longstanding that they deserve analogous recognition. ${ }^{243}$ The rhetoric the Supreme Court devoted to extolling the social value of critical inquiry in universities while constitutionalizing academic freedom in Sweezy and Keyishian can legitimately be read as judicial notice of valuable university traditions. The Court has recently observed that all public streets "are properly considered traditional public fora," making unnecessary any "particularized inquiry into the precise nature of a specific street."244 It is similarly appropriate to view all state universities as devoted to critical inquiry. This university tradition may be only a century old, ${ }^{245}$ but it is also important to realize that the Supreme Court's recognition in 1939 of the "immemorial" use of streets and parks for communication in effect reversed an 1897 decision approving an observation by Holmes that the legislature could "forbid public speaking in a highway or public park."'246

Institutional functions may change over time, as the history of American universities illustrates. Indeed, some see in American universities today an increasing tendency toward "politically correct thought" 247 that is the

241. 457 US at 879 (Blackmun concurring) (emphasis in original). See also Muir, 688 F2d at 1049 (Rubin concurring) ("Those state employees who are charged with operation of the station, whether high or low in the managerial hierarchy, may have some right to free expression, which may be stronger if, for example, they function in an academic environment devoted to freedom of inquiry.",

242. Hague v CIO, 307 US 496, 515 (1939).

243. See Bazaar v Fortune, 476 F2d 570, 580 (5th Cir 1973) (citing Sweezy and Keyishian while noting "the historical role of the University in expressing opinions which may well not make favor with the majority of society and in serving in the vanguard in the fight for freedom of expression and opinion').

244. Frisby $v$ Schultz, 487 US 474, 481 (1988).

245. See notes $32-35$ and accompanying text.

246. In Hague, 307 US at 515, the Court asserted that it had "no occasion to determine" whether its previous decision in Davis v Massachusetts, 167 US 43 (1897), "was rightly decided." The Court in Hague claimed that the ordinance in Davis "was not directed solely at the exercise of the right of speech and assembly" in a public park. Yet this attempt to distinguish Davis was unconvincing. "For the legislature absolutely or conditionally to forbid public speaking in a highway or public park," the Court concluded in Davis, "is no more an infringement of the rights of a member of the public than for the owner of a private house to forbid it in his house." 167 US at 47.

Professor Kalven's important article generating "public forum" analysis recognizes that Hague essentially reversed Davis. Harry Kalven, Jr., The Concept of the Public Forum: Cox v Louisiana, $1965 \mathrm{~S}$ Ct Rev 1, 12-13. See also Post, 34 UCLA L Rev at 1723 (cited in note 67) (asserting that the thrust of Hague "is not that speech in streets and parks is especially important or unique, but rather that government could not exercise proprietary control over such places").

247. See, for example, Scott Heller, Colleges Becoming Havens of 'Political Correctness, 'Some Scholars Say, Chron Higher Educ 1 col 3 (November 21, 1990); Carolyn J. Mooney, Academic Group Fighting the 'Politically Correct Left' Gains Momentum, Chron Higher Educ 1 col 2 (December 12, 1990); John Searle, The Storm Over the University, NY Rev Books 34 (December 6, 1990). 
antithesis of critical inquiry. If this perceived trend toward ideological conformity on issues such as faculty appointments and curriculum becomes dominant, the university itself may undermine its traditional function and with it the justification for academic freedom. But until pervasive evidence of such change exists, the Supreme Court's recognition of universities as institutions devoted to critical inquiry should prevail.

Consistent with this analysis of institutional function, the state could create institutions sharing some characteristics with universities but not devoted to critical inquiry. Illustrations could include postsecondary trade schools and legislative research bureaus employing social scientists to provide intellectual justifications for political decisions. But just as the 1915 Declaration argued that "proprietary institutions" designed to inculcate ideas should not be able "to sail under false colors" by calling themselves universities, ${ }^{248}$ states should not constitutionally be able to define as universities institutions uncommitted to critical inquiry. Once a state creates an entity described as a university, a library, a newspaper, or a television station, it should be under a first amendment obligation to respect the expressive functions traditionally associated with these institutions.

Unfortunately, a number of potential government actions raise close questions that even this extended analysis cannot answer. For example, the Supreme Court has recognized the "undoubted right" of a state legislature "to prescribe the curriculum for its public schools" as long as these laws do not otherwise violate the first amendment by constituting an establishment of religion or by discriminating against a particular ideological viewpoint. ${ }^{249}$ In relying on the establishment clause to overturn a state statute requiring instruction in "creation science," the Court recently made a special point of stating: "We do not imply that a legislature could never require that scientific critiques of prevailing scientific theories be taught."250 Various acknowledgments that greater freedom of inquiry is appropriate in universities than at earlier stages of education, combined with the university's academic freedom to determine "what may be taught" identified in the repeatedly cited passage from Sweezy, could conceivably lead the Court to impose more restrictions on legislative power to determine curriculum in state universities than in public schools. ${ }^{251}$ Yet the Court's untroubled acceptance of legislative control over public school curriculum makes the likelihood of such a holding at best uncertain. Would a court, for example, invoke first amendment academic freedom to invalidate Texas statutes requiring every state-supported university to offer a course in government or

248. See text accompanying note 23 (discussing 1915 Declaration).

249. Epperson v Arkansas, 393 US 97, 106-08, 107 n 15 (1969).

250. Edwards, 482 US at 593. See also Pico, 457 US at 869 (school boards might have "absolute discretion in matters of curriculum") (emphasis in original).

251. See DiBona, 220 Cal App3d 1329, 269 Cal Rptr 882 (Cal App 1990) (college administrators have less discretion than school administrators to control curriculum). 
political science, which must include consideration of the United States and Texas Constitutions, and a course in American or Texas history?252

The oral argument in University of Pennsylvania highlighted another unresolved challenge to the scope of institutional academic freedom against other branches of government. One justice asked the lawyer arguing on behalf of the University of Pennsylvania to specify who wields the asserted first amendment right to determine who may teach. "I guess somebody has a right to say who may teach," the justice observed, "but does it have to be the faculty?" The justice went on to wonder "what is the principle that . . members of a faculty have a constitutional right to ... replicate themselves?" Could the right to hire faculty in a state university, the justice asked, be reserved to a legislative committee or the governor?

The lawyer for the University of Pennsylvania found it difficult to respond. He claimed that it would be a "harder case" to locate this constitutional right in the legislative or the executive branches than in the faculty, but never really stated why. After some fumbling, he ultimately asserted that if, contrary to tradition, decisions about faculty hiring are made "by someone in government, then it is that entity that would enjoy the first amendment freedom." "So the government," the justice interjected, "has a first amendment right. That's phenomenal." 253

The Court's decision in University of Pennsylvania did not address the issues raised by this colloquy, but its very occurrence dramatically underlines the continuing uncertainty about the meaning of institutional academic freedom. I find it striking that the university's lawyer seemed so unprepared for this line of questioning and so readily conceded that a state legislature or governor could assume the power to appoint faculty under the protection of the first amendment. At least a plausible argument could be made that the institutional academic freedom from legislative control over university teaching established in Sweezy and Keyishian should be interpreted to preclude a state legislature or governor from appointing faculty. The first amendment interest in critical inquiry identified in those decisions is arguably threatened by the potential that political control over faculty appointments may impose a "pall of orthodoxy" over state universities and transform them into propaganda vehicles indistinguishable from government agencies such as the Voice of America.

252. Texas Educ Code Ann $\S \S 51.301,51.302$ (Vernon 1987). Professor Byrne, it seems to me, is vastly overconfident in asserting that attempts by legislatures or administrative agencies "to compel universities to offer students a particular liberal arts curriculum . . . surely would be unconstitutional" as a violation of institutional academic freedom. Byrne, 99 Yale L J at 331 (cited in note 1). Compare Thomas I. Emerson, The System of Freedom of Expression 624 (Random House, 1970) ("the government can prescribe the [broad] character of the curriculum for a particular institution, provide what general areas are to be emphasized or omitted, even require the offering of certain courses").

253. University of Pennsylvania Oral Argument at 8-10 (cited in note 214). The official transcript does not include references to particular justices. My recollection from attending the oral argument, confirmed by a law clerk who was also present, is that Justice Scalia asked these questions. 
The extent to which institutional academic freedom insulates state universities from other branches of government, though presenting numerous complicated and unresolved issues, remains largely hypothetical. In the generation since the McCarthy period, the legislative and executive branches have not intruded directly into the core academic decisions of state universities. The University of Pennsylvania decision may not have protected sufficiently the confidentiality of the peer review process from government intrusion. Yet the Court plausibly distinguished between the legislative attempts to monitor the substance of classroom speech in Sweezy and Keyishian and the EEOC's effort to determine whether the university had engaged in unlawful employment discrimination. The tension between the institutional academic freedom of universities and the individual academic freedom of faculty, by contrast, has arisen in a number of concrete contexts. It is to this difficult problem that I therefore turn.

\section{IX}

The Tension Between Individual and Institutional Academic FREEDOM

The focus of several recent Supreme Court decisions on institutional academic freedom, beginning with Bakke in 1978, has prompted some commentators to conclude that constitutional academic freedom extends only to institutions. According to these commentators, the traditional nonlegal conception of academic freedom as a right of individual faculty members, identified by the 1915 Declaration and widely accepted within the scholarly world, lacks constitutional protection. ${ }^{254}$ In my opinion, this conclusion is mistaken. The accurate perception that the Supreme Court has identified institutional academic freedom as a first amendment right does not support the additional conclusion that the Court has rejected a constitutional right of individual professors to academic freedom against trustees, administrators, and faculty peers.

Early cases such as Sweezy and Keyishian recognized constitutional academic freedom as an individual as well as an institutional right. In holding that government inquiry into the contents of a university lecture "unquestionably was an invasion of petitioner's [the lecturer's] liberties in the areas of academic freedom and political expression," the Court in Sweezy recognized both academic freedom and political expression as individual first amendment rights. ${ }^{255}$ The appellants in Keyishian were faculty members whose continued employment was conditioned on compliance with a state law requiring them to sign a certificate that they were not members of the Communist Party. ${ }^{256}$

254. See Byrne, 99 Yale L J at 255, 257,-313 (cited in note 1); Metzger, 66 Tex L Rev at 1267, 1284-85, 1292, 1322 (cited in note 1). According to Professor Metzger, the professional and constitutional definitions of academic freedom are "seriously incompatible and probably ultimately irreconcilable." Id at 1267.

255. 354 US at 250 .

256. 385 US at 591-92, 595-96. 
In holding this law unconstitutional, the Court warned that the "chilling effect upon the exercise of vital first amendment rights must be guarded against by sensitive tools which clearly inform teachers what is being proscribed."257 The law, the Court observed, could be interpreted to bar the employment of a teacher who simply informs his class about Marxism. ${ }^{258}$ The Court's emphasis on the impact of the law on teachers indicates its focus on individual interests in academic freedom.

No case to date has presented the Court with a direct conflict between institutional and individual claims of first amendment academic freedom. The closest the Court has come to analyzing this issue is a footnote by Justice Stevens in Regents of University of Michigan $v$. Ewing, ${ }^{259}$ a case brought by a medical student challenging a faculty decision to dismiss the student on academic grounds. "Academic freedom," Justice Stevens noted, "thrives not only on the independent and uninhibited exchange of ideas among teachers and students, ... . but also, and somewhat inconsistently, on autonomous decisionmaking by the academy itself ...."260 A subsequent majority opinion by Justice Brennan noted with approval the definition of academic freedom by the lower court as "the principle that individual instructors are at liberty to teach that which they deem to be appropriate in the exercise of their professional judgment." 261 In addition, the Court's recent decision in University of Pennsylvania, by facilitating discovery against a university in a Title VII case while rejecting an expanded claim of institutional academic freedom in confidential peer review material, recognized the appropriateness of judicial scrutiny of individual faculty claims against the university. Although the Court's holding applied only to EEOC subpoenas, its reasoning could easily be extended to allow discovery of personnel files by an individual professor asserting that a university appointment or promotion decision constituted employment discrimination prohibited by Title VII or retaliation for speech protected by the first amendment.

Various lower court cases, moreover, have directly addressed the tension between institutional and individual academic freedom while adjudicating disputes between individual faculty members and universities. In a decision involving the dismissal of a Marxist professor, a federal district judge frankly admitted that while academic freedom as an unenumerated first amendment right "is well recognized, its parameters are not well defined." The opinion identified "a fundamental tension between the academic freedom of the individual teacher to be free of restraints from the university administration, and the academic freedom of the university to be free of government, including judicial, interference." 262

257. Id at 604

258. Id at 600

259. 474 US 214 (1985).

260. Id at $226 \mathrm{n} 12$.

261. Edwards, 482 US at 586 n6. Justice Brennan cited this definition to evaluate its use by a state legislature, not to address its constitutional meaning.

262. Cooper $v$ Ross, 472 F Supp 802, 813 (ED Ark 1979). 
Judge Posner, whose many years as a law professor undoubtedly contributed to his appreciation of this issue, used similar language. He observed that academic freedom, though frequently described "as an aspect of the freedom of speech that is protected against government abridgment by the first amendment," has an "equivocal" meaning. "It is used to denote both the freedom of the academy to pursue its ends without interference from the government . . . and the freedom of the individual teacher (or in some versions-indeed in most cases-the student) to pursue his ends without interference from the academy; and these two freedoms are in conflict, as in this case."263 Judge Posner assumed without deciding that a university administration could not forbid the chair of the art department from displaying his stained-glass windows anywhere on campus. He acknowledged the administration's concern that the content of these windows would offend potential applicants and thus make it harder to recruit students, particularly black and female students. Judicial interference with the administration's attempt to protect the university's image, he conceded, would "limit the freedom of the academy to manage its affairs as it chooses." But he reasoned that even this legitimate interest could not justify an absolute proscription against displaying the windows, although he did uphold the administration's decision to move them to a less conspicuous place. ${ }^{264}$

Other lower court decisions, without explicitly addressing the tension between individual and institutional academic freedom, reinforce the conclusion that individual professors can have constitutional academic freedom claims against universities. In reviewing cases in which universities denied appointments to Marxist professors, courts have reiterated that "no more direct assault on academic freedom can be imagined than for school authorities to be allowed to discharge a teacher because of his or her political, philosophical, or ideological beliefs, ... . and the same would be true of a decision not to hire."265 Recent institutional policies outlawing offensive speech $^{266}$ and concerns about the danger of university and external attempts to coerce faculty research into areas likely to attract corporate and government funding 267 illustrate additional contexts that may produce individual academic freedom claims against universities.

263. Piarowski, $759 \mathrm{~F} 2 \mathrm{~d}$ at 629.

264. Id at 630. See generally id at 629-31.

265. Franklin v Atkins, 409 F Supp 439, 445 (D Colo 1976), aff'd, 562 F2d 1188 (10th Cir 1977). See also Ollman, $518 \mathrm{~F}$ Supp at 1202 .

266. See note 63 and accompanying text.

267. See Stuart W. Leslie, From Backwater to Powerhouse, Stanford 55 (March 1990) (Stanford University achieved preeminence in electrical engineering by attracting financial support and faculty from military contractors and by directing its research program and curriculum to military priorities); Eliot Marshall, Harvard Tiptoes into the Market, 241 Science 1595 (1988) (citing faculty criticism of proposed university funding for commercial development of professor's efficient method of making bacteria express human genes; concern that such projects would divert faculty from pure scholarship prompted new program to assure all funded projects are of "highest intellectual quality").

Professor Eisenberg convincingly warns that the lure of external financial support from industry and the military may tempt faculty members to compromise academic values. Rebecca $S$. Eisenberg, Academic Freedom and Academic l'alues in Sponsored Research, 66 Tex L Rev 1363 (1988). She directs 


\section{A. Are Judges Competent to Review Academic Freedom Claims By Professors Against Universities?}

Some scholars who recognize the tension between individual and institutional academic freedom advocate limiting the constitutional definition of academic freedom to the protection of the university against the state. Professor J. Peter Byrne offers the most comprehensive statement of this position. ${ }^{268}$ Byrne repeatedly argues that courts are not equipped to enforce traditional claims of academic freedom by professors against university decision-makers. ${ }^{269}$ The appropriate role of the judiciary, he maintains, is to exclude public officials from incursions into basic academic affairs, a role that in his view protects individual faculty members as well as universities as institutions. ${ }^{270}$ Byrne stresses that judges themselves are public officials who threaten academic freedom within the university. "Judicial views of civil liberty," he argues citing Schmid, "may infringe academic principles just as much as executive or legislative views of national security," 271 the impetus for the landmark academic freedom cases of the McCarthy era. For a court to resolve a faculty member's assertion that the university violated his academic freedom in denying him tenure, Byrne portentously concludes, "would put the department or school into intellectual receivership, with the court determining the appropriate paradigms of thought."272

I disagree strenuously with Professor Byrne's view that judicial review of disputes between professors and universities poses an intolerable threat of state interference with academic freedom. Title VII and first amendment cases at universities have demonstrated that judges can respect academic expertise and values while determining whether stated academic grounds are pretexts for illegal or unconstitutional university decisions. However, I generally agree with Byrne that judges should not review good faith debates within universities about the merits of unpopular or unconventional ideas.

Byrne realizes that his conception of constitutional academic freedom is inconsistent with the tradition of academic freedom derived from the 1915

legitimate criticism against recent AAUP reports on external funding of faculty research, whose focus on threats to faculty academic freedom from universities seeking external funding neglects potential abuses by professors themselves. Id at 1378-84. See, for example, AAUP, Academic Freedom and Tenure: Corporate Funding of Academic Research, 69 Academe 18a (November-December 1983); AAUP, Government Censorship and Academic Freedom, 69 Academe 15a (November-December 1983).

Professor Eisenberg and I disagree, however, about whether the traditional American conception of academic freedom constrains faculty disregard of academic values. Compare Eisenberg, id at 1404 (the "traditional American conception of academic freedom, with its emphasis on defending the professional autonomy of individual faculty members against universities, is ill-adapted to the task of protecting academic values in sponsored research within universities") with Rabban, 66 Tex L Rev at 1408 (cited in note 19) ("the traditional conception of academic freedom constrains faculty autonomy to protect academic values") and Rebecca S. Eisenberg, Defining the Terms of Academic Freedom: A Reply to Professor Rabban, 66 Tex L Rev 1431, 1434-35 (1988) (Rabban's "confusing and misleading" usage extends academic freedom beyond any meaningful definition).

268. Byrne, 99 Yale L J 251 (cited in note 1). See especially id at 255.

269. Id at 288 . See also id at $255,305,306$.

270. Id at 304. See also id at 255.

271. Id at 307. See also id at 307-08 n222.

272. Id at 306. 
Declaration, which focuses on the rights of individual professors, particularly against lay trustees or regents. ${ }^{273}$ Perhaps for this reason, he contrasts a prior "dark age of faculty dependence" with the present, "when most universities voluntarily defend the academic freedom of their faculties," 274 and the state poses the most serious threats to professors and universities. Byrne thus seems to believe that his constitutional theory of academic freedom makes both theoretical and practical sense. Not only are the courts an inappropriate forum for protecting faculty from administrators and trustees, but in the contemporary world the real dangers to academic freedom come from the state.

Byrne also constructs a "limiting principle" on institutional academic freedom that would allow some legal protection for traditional claims of academic freedom by professors against universities. According to Byrne, "constitutional academic freedom ought not to protect institutions resembling universities but which do not pursue genuine liberal studies-that prohibit or consistently discourage professors from following controversial arguments, that recognize no role for faculty in governance, or that seek to indoctrinate rather than educate students." When universities "do not respect the academic freedom of professors (understood as the core of the doctrine developed by the AAUP)," Byrne reasons, they so deviate from the values that justify institutional academic freedom that they should lose their immunity from judicial review. Byrne anticipates that his limiting principle would "lessen fears that institutional freedom will cloak extensive violations of professors' academic freedom by institutions bent on intellectual orthodoxy." 275 Yet this language suggests that as long as administrators and trustees do not "prohibit or consistently discourage" the exercise of individual academic freedom as understood by the AAUP, they retain constitutional academic freedom against judicial review of any periodic but less extensive repression of academic speech.

Legal cases and reports of AAUP investigating committees provide ample evidence that, even if the "dark age of faculty dependence" has ended (at least temporarily), university violations of faculty academic freedom continue to occur. Many of these violations, moreover, take place in universities that ordinarily respect individual academic freedom. These abridgments of academic freedom, like many state infringements of individual civil liberties, are not frequent events, and thus would not fall under Byrne's limiting principle. The broad institutional immunity advocated by Byrne would heighten the danger that administrators and trustees might violate the academic freedom of professors.

Elsewhere, Byrne seemingly departs from his limiting principle and implies that judicial review is proper whenever administrators fail to justify their decisions on academic grounds. Even under this standard, however,

273. See, for example, id at $255,267,273,288,312$.

274. Id at 324 .

275 . Id at 338 . See id at 332 . 
Byrne still insists that judges can evaluate solely whether administrators acted in good faith and not whether the grounds themselves are adequate. ${ }^{276}$ This insistence leaves a crucial problem unresolved. Determining whether an academic judgment purportedly made in good faith is actually a pretext for an improper consideration, including one that might violate individual academic freedom, often requires some assessment of the adequacy of the stated academic ground.

Byrne confuses his analysis by referring to university administrators as "lay persons" in some contexts but as "academics" in others. In discussing the historical roots of the AAUP's conception of individual academic freedom, Byrne recognizes that university presidents, whatever the identification they might previously have had with the faculty, had become "institutional executives and educational entrepreneurs," who shared the business values of trustees more than the academic values of professors. ${ }^{277}$ Byrne applauds the emphasis in the 1915 Declaration on the relationship between peer review and academic freedom, deeming it "the insulation of the individual professor from lay interference." 278 Byrne here understands that the laity includes administrators as well as trustees, although in discussing threats to the academic freedom of professors he focuses more on trustees than on administrators. ${ }^{279}$

In analyzing judicial review of universities' academic decisions, by contrast, Byrne groups administrators with faculty as academics, while largely ignoring trustees. He refers to "intra-academic" cases, ${ }^{280}$ in which faculty members claim violations of their academic freedom by "other academics, usually administrators and department chairs." 281 Byrne may be correct that some administrators are presumptively competent to apply professional criteria in judging academic speech, ${ }^{282}$ but this presumption weakens as one moves up the hierarchy of university administration, and it is invalid as to trustees.

Byrne finds it "incoherent to suggest that academic freedom could be furthered by reducing peer review and substituting the enforcement of rules by lay persons such as judges." Such a transformation "ignores both the historical basis of, and the actual structures that protect, faculty rights." ${ }^{283}$ I

276. See id at $300,304,306,308$.

277. Id at 270 . See id at 272.

278. Id at 278 .

279. Id at $273,276$.

280. Id at 309.

281. Byrne in this context finds it reasonable for the AAUP, but not for the courts, to criticize administrators who reject the professional judgments of faculty committees "because it is that association's business to enhance the sphere of freedom and control over academic administration of its members." This language portrays a self-interested power struggle between faculty and administrators that seems inconsistent with Byrne's repeated approval of peer review as a safeguard of individual academic freedom against inappropriate intrusions by lay administrators and trustees. At most, Byrne is willing to concede that this struggle may produce "workable norms" that should not be enforced in "the coercive domain of law." Id at 308.

282 . Id at 310.

283. Id at 286 . 
emphatically agree. But this passage does not address the propriety of lay persons such as judges enforcing peer review, and thereby protecting individual academic freedom, against other lay persons such as trustees and administrators. The theory that justifies judicial as well as administrative deference to peer review does not support similar judicial deference to trustees and administrators.

In addition, Byrne's examples of the dangers inherent in judicial review of individual academic freedom claims against universities are frequently inapt. He seems to assume, for example, that a constitutional right of individual academic freedom would force courts to overturn administrative sanctions against professors who deviate from prescribed curricular coverage or who receive poor teaching evaluations from students. ${ }^{284}$ But no accepted theory of individual academic freedom, and certainly not the one developed by the AAUP, would identify these professors as engaging in speech to which academic freedom should attach. Academic freedom is not the freedom to be a poor teacher or to refuse to include materials on the Civil War in a survey course in American history.

Byrne also assumes erroneously that a constitutional right of individual academic freedom would be violated if a university administrator, shocked that the philosophy department has no expert on Plato and Aristotle, denies tenure to a creative philosopher with an esoteric specialty. ${ }^{285}$ Even if the administrator had overruled a unanimous departmental recommendation, the justification behind this decision reflects the kind of legitimate bureaucratic concern over departmental balance that provides grounds for reversing peer judgments under policies the AAUP accepts. Bureaucratic rationales similarly would justify rejections of peer recommendations by administrators based on programmatic or financial grounds, the candidate's professionally unethical conduct, or the failure of peers to apply appropriate professional standards. ${ }^{286}$ By contrast, individual academic freedom would be implicated if administrators denied tenure to a candidate because they feared his eclectic interest in unpopular philosophical positions would alienate a potential donor.

The most important response to Byrne is that judges can enforce the academic freedom of individual professors against administrators, trustees, and faculty peers without violating a legitimate conception of institutional academic freedom or abandoning appropriate judicial deference to academic decision-making. The judiciary is more deliberative and less political than

284. Id at 301 .

285. Id at 308 .

286. See AAUP, American Council on Education, and Association of Governing Boards of Universities and Colleges, 1966 Statement on Government of Colleges and Universities, reprinted in Academic Freedom and Tenure at 90 (cited in note 6) ("Statement on Government"). See generally Rabban, 66 Tex L Rev at 1411-12 \& n29 (cited in note 19). David M. Rabban, Distinguishing Excluded Managers From Covered Professionals Under the NLRA, 89 Colum L Rev 1775, 1840-44 (1989), analyzes the legitimate bureaucratic responsibilities of managers in universities and other organizations in which professionals work. 
either the legislature or the executive. Indeed, in these respects courts may resemble universities more than other branches of government. Courts are likely to be more sensitive than legislators or members of the executive branch ${ }^{287}$ to the need for independent critical inquiry in universities and to their democratic role as sanctuaries for unpopular ideas. These statements are not merely speculative. A model for appropriate judicial review of individual academic freedom cases already exists in numerous decisions addressing claims by professors that universities have violated Title VII prohibitions against employment discrimination or general rights of free speech protected by the first amendment.

\section{B. Appropriate Judicial Review of Academic Decisions}

Title VII and first amendment decisions demonstrate that judges, without undue interference in university affairs, can review whether stated academic grounds are pretexts. Whatever their holdings, these decisions emphasize that courts should afford broad deference to professional expertise. Academic decisions are necessarily subjective and beyond the competence of judges. Courts cannot become a "Super-Tenure Review Committee"288 or "evaluate the substance of the multitude of academic decisions that are made daily by faculty members of public educational institutions." 289 Rather, judges should override "a genuinely academic decision" only if "it is such a substantial departure from accepted academic norms as to demonstrate that the person or committee responsible did not actually exercise professional judgment.",290

This standard of judicial review, as the courts announcing it have recognized, requires judges to evaluate the substance of the decision so that they can determine whether "a substantial departure from accepted academic norms" took place. In applying this standard, courts stress that decisions by professionals are "presumptively valid"291 and are subject to "very limited"'292 judicial scrutiny. If a professional decision has "an adequate factual basis for the conclusions reached," 293 a court should not substitute its judgment on the merits for the views of the relevant professionals. The role of judges is not to review and correct individual mistakes in academic decision-making, but to make sure that the decisions reached by professionals

287. See Alexander Bickel, The Least Dangerous Branch: The Supreme Court at the Bar of Politics 25-26 (Yale, 2d ed 1962); Henry P. Monaghan, First Amendment "Due Process," 83 Harv L Rev 518, 523-24 (1970). See also AAUP, Academic Freedom and Tenure: State University of New York at Stonybrook, 76 Academe 55 (January-February 1990) (AAUP investigating committee concludes that professor, accused of equating Zionism with racism, protected by academic freedom against interference by state governor and others outside the university in internal review of his candidacy for tenure).

288. Keddie v Pennsylvania State University, 412 F Supp 1264, 1270 (MD Pa 1976).

289. Ewing, 474 US at 226.

290. Id at 225 .

291. Youngberg $v$ Romeo, 457 US 307, 323 (1982), cited in Ewing, 474 US at 225.

292. Cooper, 472 F Supp at 810 .

293. Ollman, 518 F Supp at 1215 . 
are consistent with constitutional and statutory obligations. ${ }^{294}$ Not surprisingly, these stringent standards have prompted courts to reject the overwhelming majority of Title VII and first amendment claims by individual professors against universities.

Several courts, concerned that appropriate judicial deference to academic decision-making "has been pressed beyond all reasonable limits," have warned against a policy of judicial "self-abnegation where colleges are concerned" that amounts to "abdication" of responsibility to enforce laws protecting individual rights. ${ }^{295}$ Academic freedom, they stress, does not include the freedom to engage in employment discrimination or to violate the free speech protected by the first amendment. ${ }^{296}$ Even courts that do not express this concern look into the factual background of academic decisions to determine whether a stated academic judgment was a pretext.

The Supreme Court has yet to address the merits of an individual claim by a faculty member against peers, the administration, or the trustees, although University of Pennsylvania makes clear that the Court is prepared to do so. ${ }^{297}$ However, the Court has reviewed faculty professional judgment in a case brought by a dismissed student. While stressing the importance of judicial deference, the Court felt compelled to examine the evidence underlying the faculty judgment before upholding it. The Court pointed out, for example, that the dismissed student had low grades, many incomplete courses, irregular or reduced course loads, and had failed his medical boards. ${ }^{298}$

Lower courts have adopted a similar approach to Title VII and first amendment claims by faculty members against university decision-makers. In reviewing a claim that a university president unconstitutionally relied on a professor's Marxist beliefs to reject him for department chair, one judge emphasized that the president's reasons "must be examined critically and in detail."299 A thorough analysis of the record convinced the judge that the president's reasons were not only sincere but also supported by sufficient evidence. ${ }^{300}$

294. See, for example, Brown v Trustees of Boston University, 891 F2d 337, 356 (1st Cir 1989); Clark v Whiting, 607 F2d 634, 639 (4th Cir 1979); Cooper, 472 F Supp at 810.

295. Powell $v$ Syracuse University, 580 F2d 1150, 1153, 1154 (2d Cir 1978), citing Sweeny v Board of Trustees of Keene State College, 569 F2d 169, 176, 177 (1st Cir 1978), judgment vacated, 439 US 24 (1978), appeal after remand, 604 F2d 106 (1st Cir 1979).

296. Powell, $580 \mathrm{~F} 2 \mathrm{~d}$ at $1154 ;$ Brown, $891 \mathrm{~F} 2 \mathrm{~d}$ at 360 .

297. The Supreme Court's recent decision in University of Pennsylvania, $110 \mathrm{~S} \mathrm{Ct} 577$, by facilitating discovery against a university in a Title VII case, recognizes the appropriateness of judicial review of individual faculty claims. The Court emphasized that Congress explicitly discounted the danger of improper state intrusion into university autonomy when it amended Title VII in 1972 to cover educational institutions, which were exempted under the original 1964 legislation. Id at 582. University decisions based on race, sex, or national origin, the Court observed, do not constitute the "academic grounds" protected by the first amendment right to academic freedom. Id at $587 \mathrm{n} 7$. The Court thus concluded that judges can enforce Title VII on campus while recognizing "the importance of avoiding second-guessing of legitimate academic judgments." Id at 587.

298. Ewing, 474 US at 227.

299. Ollman, 518 F Supp at 1203.

300. Id at 1215 . 
Given the understandable concern about the competence of judges to evaluate sensitive and subjective academic decisions requiring professional expertise, it is striking how much of the evidence cited by judges in Title VII and first amendment cases does not fall into this category. Rather, evidence of pretext has frequently involved familiar judicial analysis of motivation based on factors that are not unique to a university environment, such as the timing of a decision and objective quantitative data. One court found that university administrators had violated a professor's first amendment rights based on two key facts: the university had never previously dismissed or failed to renew the contract of a full-time faculty member, and the university administrators refused to reappoint the plaintiff almost immediately after he created a state-wide public controversy by announcing his belief in communism and his membership in the Progressive Labor Party. These facts convinced the court that the faculty member's protected first amendment speech and association, and not weaknesses in his teaching as the administrators asserted, were the primary factors in the decision against reappointment. ${ }^{301}$

Similar examples abound. Testimony that the administration required publication of two books from a female professor who was denied tenure, but only one book from men who had received tenure, helped an appellate court in a Title VII case reach the inference that the administrators' vigorous criticism of her scholarship was a pretext for discrimination. ${ }^{302}$ Another judge upheld a finding of discrimination based on uncontroverted evidence that a black administrator failed to renew the contract of a white professor whose formal educational background met or exceeded those of black colleagues who were retained and promoted. ${ }^{303}$ On the other hand, a court that complained about too much judicial deference to universities in Title VII cases nevertheless affirmed the termination of a black female professor who had established a prima facie case of discrimination. The court based its holding in part on the fact that the professor lacked formal training in architecture, the field in which she taught. ${ }^{304}$

Although much of the evidence in these cases did not require judicial analysis of sensitive professional judgments, courts have been willing when necessary to evaluate the substance of academic decisions to determine whether stated academic grounds were pretextual. One judge concluded that a candidate for department chair did not have sufficient administrative experience, and reviewed the conflicting testimony of distinguished scholars to determine whether doubts about the candidate's academic qualifications were plausible. ${ }^{305}$ In another case, a circuit court evaluated a complex academic judgment - that a woman denied reappointment lacked the ability to

301. Cooper, 472 F Supp at 811-12.

302. Brown, $891 \mathrm{~F} 2 \mathrm{~d}$ at 347.

303. Whiting v Jackson State University, 616 F2d 116, 123-24 (5th Cir 1980).

304. Powell, 580 F2d at $1151,1156$.

305. Ollman, $518 \mathrm{~F}$ Supp at 1217. 
generalize from her admitted competence in her specialized research field to broader issues in her discipline-to determine whether this criterion was applied fairly not just to her, but also to men who were reappointed in the same department. ${ }^{306}$

Courts have cited "obviously weak or implausible" 307 and "ambiguous and poorly substantiated" 308 statements of reasons for personnel decisions as relevant to determining whether stated academic judgments were pretextual. Significantly, even in so doing, one court reiterated that the merits of academic decisions are within university discretion and involve subtle issues that may be difficult to articulate. Universities, the court added, need not ordinarily document or explain their tenure decisions. Yet in analyzing a claim that a university had violated a faculty member's first amendment rights, "the paucity of supporting evidence implies that the reasons given by the University were hastily prepared makeweight reasons which do not fully reflect its true motivation." 309 The unanimous recommendations of faculty committees have also prompted courts, consistent with the theory of peer review, to be skeptical of the administration's stated academic grounds for reversing them. ${ }^{310}$

\section{Judicial Review of Internal Debates Over Professional Quality}

I have attempted thus far to demonstrate that individual academic freedom is a meaningful concept under the first amendment. Courts have recognized its existence in tension with institutional academic freedom, and judicial techniques for reviewing faculty claims against university decision-makers in Title VII and general first amendment cases can be applied as well to individual claims of academic freedom without undermining critical inquiry. Yet some professors do not allege that stated academic reasons are pretexts, but that those reasons themselves violate academic freedom by relying on intellectual orthodoxies. The university decision-makers may respond that the candidate is not simply unorthodox, but professionally incompetent or undistinguished. Should judges resolve disputes within the university about whether unpopular or unconventional ideas reflect professional merit?

Many of these internal academic debates raise issues that could be brought under conventional Title VII and first amendment theories. Departments of linguistics, English, and economics might tell disappointed candidates for appointment or tenure that studies of black dialects, feminist literary theory, and Marxist economic analysis simply are not useful modes of professional inquiry. Are these reasons evidence of racial, sexual, or political discrimination? Without raising broader issues of discrimination,

\footnotetext{
306. Smith v University of North Carolina, 632 F2d 316, 342-44 (4th Cir 1980).

307. Brown, $891 \mathrm{F2d}$ at 346, citing Kumar v Board of Trustees, University of Massachusetts, 774 F2d 1, 12 (1st Cir 1985) (Campbell concurring).

308. Cooper, 472 F Supp at 812 .

309. Id.

310. Brown, 891 F2d at 347-48; Kunda v Muhlenberg College, 621 F2d 532, 548 (3d Cir 1980).
} 
departments may consider quantitative analysis in history or cataclysmic theories of biological change as professionally uninteresting. Do these evaluations impose an ideological orthodoxy that violates the academic freedom of professors denied appointment or tenure because they hold such views? ${ }^{311}$

Recent controversies over the value of "critical legal studies" in law schools prompted the AAUP to address these issues. Though the AAUP admonished departments to base decisions on the professional competence and integrity of candidates rather than on disciplinary orthodoxies, it did not address the extent to which standards of competence within disciplines themselves reflect conventional wisdom. The AAUP concluded that departments do not abridge individual academic freedom as long as they make academic judgments in good faith, a permissive though largely undefined standard. Evidence of bad faith, the AAUP suggested, might include consideration of the possible consequences of a candidate's academic views or penalizing a candidate's "nihilism" about her discipline. ${ }^{\mathbf{3} 2}$

Unfortunately, too many academics find no merit in disciplinary approaches that differ from their own. This position, though narrow and arrogant, may be held in good faith. Indeed, professors who are most obnoxiously confident in the superiority of their own views are also most likely to be acting in good faith.

It is often impossible, moreover, to separate ideological from disciplinary objections to academic work. Does a liberal law professor oppose critical legal studies or the Chicago school of economics because he has political objections to radical and conservative positions, or because he finds little merit in their intellectual approaches to legal issues? Does a radical law professor favor critical and feminist legal theory over traditional doctrinal analysis for intellectual or political reasons? Perhaps in an extremely rare case, a court reasonably could conclude that a claimed disagreement over merit constitutes unjustifiable disciplinary orthodoxy. For example, the explanation by a mediocre university that a prolific and nationally recognized scholar with unorthodox views does not meet its academic standards could legitimately be rejected by a court. But in most cases, where such enormous disparities could not be proved, I favor judicial deference to departmental decisions as long as stated disciplinary judgments are plausible and are not pretexts.

311. See Judith Jarvis Thomson, Ideology and Faculty Competence, 53 L \& Contemp Probs 155 (Summer 1990).

312. AAUP, Some Observations on Ideology, Competence, and Faculty Selection, 72 Academe la (JanuaryFebruary 1986). An essay by Paul D. Carrington, Of Law and the River, $34 \mathrm{~J}$ Legal Educ 222 (1984), which contained the statement that "the nihilist who must profess that legal principle does not matter has an ethical duty to depart the law school," id at 227, led to this AAUP document. Correspondence provoked by Carrington's article is collected in "Of Law and the River, " and of Nihilism and Academic Freedom, $34 \mathrm{~J}$ Legal Educ 1 (1985). Rabban, 66 Tex L Rev at 1424-27 (cited in note 19), discusses the tension between the academic freedom of the candidate and the academic freedom of peer review committees in the context of disagreements about the value of a candidate's approach to a discipline. 
In my opinion, critical inquiry is assisted by the inclusion of opposing intellectual perspectives within the same institution, and professors should try hard to find merit in disciplinary approaches they oppose. I object, however, to constitutionalizing my own view about appropriate intellectual balance. I agree with Professor Byrne that courts should not adopt a theory of individual academic freedom that protects "all arguably respectable points of view,"31s and impose on universities unwanted professors opposed by the existing faculty in good faith on academic grounds. As Justice Stevens has effectively pointed out, the academic judgments of universities, including the decisions to "hire professors on the basis of their academic philosophies" and to. "reward scholars for what they have written," should not be judged by the same "compelling state interest" standard that applies generally to state regulation of the content of speech. ${ }^{314}$

Byrne essentially incorporates a good faith standard similar to the AAUP's into his analysis of constitutional academic freedom, and extends it to academic decisions by administrators as well as by faculty committees. ${ }^{315}$ Byrne never explicitly addresses administrative or trustee reversals of academic judgments by faculty committees. Yet his general reluctance to allow judicial review of internal university disputes over academic issues suggests that he would also favor judicial abstention in this context, despite his recognition that the system of peer review protects the academic freedom of professors from interference by administrators and trustees.

Policies broadly adopted within the academic world, by contrast, suggest that administrators and trustees are not entitled to the same deference regarding academic issues as are faculty peers. The 1966 Statement on Government of Colleges and Universities, endorsed by the AAUP, the American Council on Education, and the Association of Governing Boards of Universities and Colleges, identifies the appropriate roles of different constituencies in the shared system of university governance. Reflecting the relationship between peer review and academic freedom, the 1966 Statement asserts that in matters of faculty status, the governing board and the administration "should concur with the faculty judgment except in rare instances and for compelling reasons which should be stated in detail."316 The Statement does not elaborate what these compelling reasons are, but the 1915 Declaration and essays on academic freedom by AAUP leaders indicate that they include the failure of peer review bodies to follow professional standards. ${ }^{317}$ As one AAUP president observed, sometimes university administrators and trustees have protected the academic freedom of individual professors from faculty colleagues. ${ }^{318}$ Presumably, the

313. Byrne, 99 Yale $\mathrm{L} J$ at 306 (cited in note 1).

314. Widmar, 454 US at 277-78 (Stevens concurring).

315. Byrne, 99 Yale L J at 306-08 (cited in note 1).

316. Statement on Government at 99 (cited in note 286).

317. 1915 Declaration at 169-70; Appendix A at 402 (cited in note 6).

318. Fritz Machlup, On Some Misconceptions Concerning Academic Freedom, reprinted in Academic Freedom and Tenure at $177,182-83$ (cited in note 6). 
departmental bad faith recently identified by the AAUP ${ }^{319}$ would constitute failure to follow professional standards, as would evidence that faculty peers voted for candidates based on friendship or politics, rather than on their academic merits, an accusation increasingly levelled against academic leftists. ${ }^{320}$ A number of professors, for example, have recently claimed that they were denied reappointment or tenure because they did not follow a radical party line on issues involving the Third World or were too "Eurocentric." 321

This analysis suggests judicial deference to administrators who present plausible evidence that faculty committees have deviated from professional standards. But what if no such compelling reasons exist to overturn the academic judgments of faculty bodies? What if administrators or trustees simply disagree with peer assessments of a candidate's academic qualifications? Should courts intervene in the name of academic freedom and protect the proper operation of peer review, particularly when universities themselves adopt the structure of shared governance endorsed by the 1966 Statement?

Judicial enforcement of faculty academic judgments reversed by administrators or trustees without compelling reasons would support the peer review process that contributes to academic freedom. In order to determine whether administrators or trustees have produced sufficient evidence for reversing peer evaluations, judges might have to assess the substance of an academic decision. But judges already perform this task competently, though hesitantly, in determining whether stated academic evaluations are pretexts for reasons that violate Title VII or the first amendment. In addition, courts would not be making entirely independent judgments. They presumably would give greater weight to the more professional decision-maker, defined by the Supreme Court as "a person competent, whether by education, training or experience, to make the particular decision at issue." ${ }_{222}$ In Ewing, the Court deferred to the professional judgment of the faculty in upholding the student dismissal. ${ }^{323}$ With respect to evaluations of professional merit, in contrast to bureaucratic concerns such as finances or abuse of professional discretion, the faculty peers, not the administrators or trustees, meet this definition.

I nevertheless share Byrne's reluctance to allow judges to decide good faith disputes between faculty committees and administrators or trustees about matters of professional quality. Though not as draconian as Byrne maintains, such a judicial role constitutes much more intrusion into academic life than does judicial review of the merits of a decision to determine whether a stated academic reason is a pretext. A constitutionally mandated policy that

319. See note 312 and accompanying text (discussing AAUP treatment of departmental bad faith).

320. See Searle, NY Rev Books at 34 (December 6, 1990) (cited in note 247).

321. Heller, Chron Higher Educ at 1 col 3 (cited in note 247).

322. Youngberg, 457 US at $323 \mathrm{n} 30$.

323. 474 US at $225-28$. 
faculty committees always prevail over administrators and trustees in good faith disputes over a professor's academic quality seems different in kind from a constitutional requirement that judges must reverse a denial of appointment or tenure upon finding that faculty peers, administrators, or trustees, though claiming that the candidate lacked sufficient qualifications, actually based the decision on ideological objections unrelated to merit or on fear that the candidate's scholarly positions would alienate important legislators and alumni. The 1966 Statement provides an excellent illustration of Byrne's point that not all desirable university policies should be incorporated into a constitutional definition of academic freedom. ${ }^{324}$ However, administrative rejections of peer recommendations on matters of faculty status, because they should occur only "in rare instances and for compelling reasons" given faculty expertise in this area, can provide grounds for suspecting that the administrators were not acting in good faith and for examining the stated reasons more closely. Judicial decisions in Title VII and first amendment cases recognize this point by citing, as evidence of pretexts, administrative reversals of unanimous faculty recommendations and weak statements of reasons. ${ }^{325}$

\section{The Status of Intramural Speech on University Affairs}

Individual professors often claim the protection of academic freedom for intramural speech on university affairs as well as for the views they express in teaching and scholarship. Whether intramural speech by individual professors merits protection under the first amendment is an important topic of current scholarly and judicial debate. I address this issue here to provide a more complete analysis of the tension between individual and institutional academic freedom under the first amendment.

The status of intramural speech by professors has enormous practical significance, for disputes over university policies and personalities have far outnumbered classic academic freedom cases involving the content of teaching or scholarship. ${ }^{326}$ The Supreme Court has limited the general first amendment right of intramural speech by public employees to matters of "public concern" and to speech that does not unduly impair efficient and harmonious employment relations. ${ }^{327}$ Applying this standard, many lower courts have found that speech by professors on a variety of institutional matters either does not involve public concerns or impairs institutional efficiency or harmony. ${ }^{328}$ The limited general first amendment protection for intramural speech, combined with the large number of disputes over this issue

324. Byrne, 99 Yale $\mathrm{LJ}$ at 308-09 (cited in note 1).

325. See notes $307-10$ and accompanying text.

326. Matthew W. Finkin, Intramural Speech, Academic Freedom, and the First Amendment, 66 Tex L Rev 1323, 1337-38 (1988); Metzger, 66 Tex L Rev at 1276 (cited in note 1).

327. Connick v Myers, 461 US 138 (1983). The Court stressed in Connick that it would not "constitutionalize" into a matter of public concern every grievance by a public employee. Id at 154 . 328. Finkin, 66 Tex $L$ Rev at 1325-27 (cited in note 326), provides examples. 
at American universities, tempts professors to invoke academic freedom as a way to provide constitutional coverage that otherwise would not exist.

Yet as Professor Van Alstyne has effectively demonstrated, the "promiscuous usage" of the term "academic freedom" to cover aprofessional political speech has debased its meaning through overgeneralization and has impeded judicial recognition of a legitimate, distinctive theory of academic freedom as a subset of general first amendment rights. ${ }^{329}$ The same danger, it seems to me, applies to disputes over intramural speech. A specific academic freedom right to intramural speech, like other claims relying on academic freedom, must be distinguished from general first amendment principles and justified in reference to the value of critical inquiry that academic freedom promotes. If general first amendment principles governing intramural speech are as inadequate today as the general first amendment principles governing aprofessional political speech were in 1915, the appropriate response is to convince the courts to develop a better first amendment theory covering the intramural speech of all public employees. ${ }^{330}$ It would be illogical, and probably counterproductive, to leverage special protection for professors on an extension of the specific theory of academic freedom beyond its legitimate justifications.

Measured by their contribution to critical inquiry, the contents of intramural speech reflect a wide spectrum. Faculty complaints about an institution's parking or medical policies, though they could be connected very indirectly to a professor's teaching and research, are too remote from the value of critical inquiry to justify protection under a specific constitutional theory of academic freedom. ${ }^{331}$ Claims by faculty members that the administration or governing board has violated the academic freedom of colleagues seem to fall at the other end of this spectrum. Such claims do not involve the teaching or scholarship of the actual complainants, but do seem sufficiently related to concerns about critical inquiry to merit the coverage of individual academic freedom. Much intramural speech falls between these examples. Claims of administrative abuse of the peer review process and disagreements over curricular and other educational policy issues seem sufficiently linked to critical inquiry to come within the specific theory of academic freedom. Disputes over salary or office space do not. ${ }^{332}$ For me, close cases include disputes over student admissions policies and the allocation of financial resources to the library.

The key issue, however, is not how a particular close case should be resolved, but the recognition that some intramural speech on matters beyond an individual's teaching and scholarship should be protected by a first amendment right of academic freedom. Examining whether intramural

329. Van Alstyne, The Specific Theory of Academic Freedom at 60 (cited in note 22).

330. See Paul Brest, Protecting Academic Freedom Through the First Amendment: Raising the Unanswered Questions, 66 Tex L Rev 1359, 1362 (1988).

331. See Mark G. Yudof, Intramural Musings on Academic Freedom: A Reply to Professor Finkin, 66 Tex

L Rev 1351, 1356 (1988).

332. See id at $1355-56$. 
speech promotes critical inquiry-the touchstone of academic freedom analysis-may lead to different results than examining whether intramural speech raises issues of public concern, which is the touchstone of general first amendment analysis. For example, a debate within a department over a candidate's qualifications for tenure is less a matter of public concern, but more related to critical inquiry, than accusations that a university president abused office for financial gain. One could argue that the special theory of academic freedom and general first amendment principles converge in the context of intramural speech, because any topic related to critical inquiry is also a matter of public concern. This argument, however, seems to stretch the concept of public concern beyond its plausible limits. Such issues as the decline in educational standards at a state university, on the other hand, may be both matters of public concern and closely related to critical inquiry. Moreover, under the general first amendment analysis of intramural speech, the focus on employee harmony may be less salient in an academic context, where debate is expected and even encouraged, than in other areas of public employment. ${ }^{333}$

Although the courts have not distinguished a specific theory of academic freedom from general first amendment principles regarding intramural speech, the separate opinions of Justices Brennan and Marshall in Minnesota State Board for Community Colleges v. Knight, while reaching different conclusions in that case, suggest some appreciation of the relationship between intramural speech and academic freedom. The majority in Knight refused to recognize a "constitutional right of faculty to participate in policymaking in academic institutions." "334 "Faculty involvement in academic governance has much to recommend it as a matter of academic policy," the Court concluded, "but it finds no basis in the Constitution."335

Justice Brennan dissented based on his interpretation of the first amendment protection for academic freedom. "The first amendment freedom to explore novel or controversial ideas in the classroom is closely linked to the freedom of faculty members to express their views to the administration concerning matters of academic governance."336 In his opinion, "a direct prohibition of some identified faculty group from submitting their views concerning academic policy questions for consideration by college administrators would plainly violate principles of academic freedom enshrined in the first amendment." 337

333. See, for example, Johnson $v$ Lincoln University of Com. System of Higher Educ., 776 F2d 443, 454 (3d Cir 1985), citing "academic context" in finding first amendment protection for faculty criticism of university president; Mabey v Reagan, 537 F2d 1039, 1048 (9th Cir 1976) (less need for harmony in college than in high school); Landrum $v$ Eastern Kentucky Univ., 578 F Supp 241, 246 (ED Ky 1984) ("there must be more room for divergent views in a university situation than in a prosecutor's office").

334. 465 US 271,287 (1984).

335. Id at 288 .

336. Id at 296-97 (Brennan dissenting).

337. Id at 297. 
Justice Marshall, by contrast, concurred in the majority's decision, reasoning that courts should be less suspicious of restraints on faculty speech by university administrators than by state legislators. He concluded that universities are most likely to fulfill their social mission when they retain autonomy from external interference. Courts should therefore "defer to the judgment of college administrators-persons we presume to be knowledgeable and to have the best interests of their institutions at heart-in circumstances in which we should not defer to the judgment of government officials who seek to regulate the affairs of the academy." 338

Yet Justice Marshall maintained that in an appropriate case he would be prepared to include within the first amendment "a measure of freedom on the part of faculty members (as well as students) to present the college administrators their ideas on matters of importance to the mission of the academic community." Such freedom, he added, is essential for universities "to advance the frontiers of knowledge through unfettered inquiry and debate." 339 As Justice Marshall's concurrence suggests, one could agree with the majority that the first amendment does not require faculty participation in university governance, yet still maintain that the individual right of academic freedom under the first amendment protects faculty speech on matters of educational policy related to the value of critical inquiry. Indeed, the majority opinion, without referring explicitly to academic freedom, emphasized the district court finding that all faculty retained their associational and free speech rights to communicate with administrators about matters of educational policy. ${ }^{340}$

\section{E. Should Procedural and Structural Protections for Faculty Academic Freedom be Included Within the First Amendment?}

The AAUP and academic commentators often emphasize the importance of various procedural and structural protections for academic freedom, such as peer review, tenure, and faculty participation in university governance. The Supreme Court has recognized in various nonacademic contexts that procedural standards are necessary to protect substantive free speech rights and has interpreted the first amendment to incorporate certain procedural guarantees. Professor Henry Monaghan has felicitously labelled this development "first amendment 'due process." "341 Notice, access to information, and rights to appeal during the tenure process are examples of procedural claims related to academic freedom. One could also argue that certain structural arrangements, such as peer review and faculty participation in university governance, similarly are necessary to protect first amendment rights of individuals and institutions. Professor Byrne, for example, maintains that "the structural mechanisms within the university that give precedence to

338. Id at 294-95 (Marshall concurring).

339. Id at 293.

340. Id at $277-78 \mathrm{n} 4,288$.

341. Monaghan, 83 Harv L Rev 518 (cited in note 287). 
peer judgment . . . determine the content of academic freedom." 342 "Academic freedom," he adds, "has no meaning without peer review."343 Yet, as Knight illustrates, the Supreme Court has rejected extending first amendment academic freedom this far.

The Supreme Court's initial and most significant refusal to incorporate faculty procedural interests within the first amendment occurred in a pair of 1972 decisions addressing the rights of nontenured faculty members denied reappointment at state universities: Board of Regents $v$. Roth ${ }^{\mathbf{3 4 4}}$ and Perry $v$. Sindermann. ${ }^{345}$ The AAUP filed briefs in both of these cases, arguing that some procedural safeguards for nontenured faculty members are necessary to protect their academic freedom. The relationship between procedural and substantive rights, the AAUP emphasized, "is most significant in higher education, where the Court's special concern for academic freedom is at stake. It would be anomalous to hold that while all faculty members enjoy academic freedom in the classroom and outside, only tenured faculty are effectively able to vindicate or exercise that freedom." 346

The Supreme Court rejected the AAUP's position. The Court acknowledged previous holdings requiring the opportunity for a fair hearing before state actions that "would directly impinge upon interests in free speech or free press." Examples included the seizure of allegedly obscene books and an injunction against public rallies. Yet the Court denied that the nonrenewal of a faculty member constituted an analogous context. "Whatever may be a teacher's rights of free speech," the Court reasoned, "the interest in holding a teaching job at a state university, simpliciter, is not itself a free speech interest." 347

Just as the AAUP sought to encompass within first amendment academic freedom some procedural protections for nontenured faculty members in Roth and Perry, it attempted in University of Pennsylvania to attach first amendment weight to the institution's peer review process. ${ }^{348}$ Once again, the Supreme Court was not convinced. Indeed, the Court sardonically and gratuitously deprecated the value of peer review. After observing that

342. Byrne, 99 Yale $\mathrm{L} J$ at 267 (cited in note 1).

343. Id at 319. See generally id at 267, 310-11, 318-20.

344. 408 US 564.

345. 408 US 593.

346. AAUP's Brief as Amicus Curiae at 28, Perry v Sindermann, 408 US 593 (1972) (No 70-36). See also id at 11, 22-23, 26-28; AAUP's Brief as Amicus Curiae at 7-9, 14, Board of Regents $v$ Roth, 408 US 564 (1972) (No 71-162). The AAUP briefs in these cases did not attempt to specify the procedures necessary to protect the substantive right of academic freedom or to clarify the relationship between academic freedom and the first amendment. But see William W. Van Alstyne, The Constitutional Rights of Teachers and Professors, 1970 Duke L J 841, 860-61 (the "first amendment itself implicitly affords the right to a pretermination hearing or at least to some right of efficacious intramural or administrative review sufficient to assure the timely protection of freedom of speech").

347. Roth, 408 US at $575 \mathrm{n} 14$. Dissenting, Justice Douglas seemed essentially to agree with the AUAP approach. He quoted the district court statement that "[s]ubstantive constitutional protection for a university professor against non-retention in violation of his First Amendment rights or arbitrary non-retention is useless without procedural safeguards." Yet Douglas referred to these procedural safeguards as due process "apart from the First Amendment." Id at 585.

348. AAUP University of Pennsyluania Brief at $10 \mathrm{n} 9$ (cited in note 170). 
taxation or other government regulation of universities, without violating the first amendment, might deprive them of money they could otherwise use to attract professors, the Court added: "We doubt that the peer review process is any more essential in effectuating the right to determine 'who may teach' than is the availability of money."349 This dictum might be only a sign of judicial frustration with an "extremely attenuated" university claim based on dubious assumptions about the need for confidentiality in tenure evaluations. It does, however, reinforce the Court's reluctance in Roth and Perry to extend constitutional academic freedom to procedural protections for this substantive right. The Court's rejection in Knight of Justice Brennan's position that first amendment academic freedom includes faculty participation in university governance provides additional evidence of this reluctance to safeguard more than the substance of academic speech. ${ }^{350}$

In my opinion, the inclusion of procedural and structural protections within constitutional academic freedom is defensible but not necessary. The "first amendment 'due process'" recognized in other contexts can plausibly be extended to academic freedom. The right to a faculty position may not itself be a free speech interest. But critical inquiry about professional issues, the key function of professors, depends, as do other substantive free speech rights, on procedural and structural safeguards. If universities can summarily dismiss controversial faculty members, for example, the social benefits of critical inquiry safeguarded by the individual academic freedom of professors may too easily be impaired.

On the other hand, the Supreme Court's apparent limitation of individual academic freedom under the first amendment to a substantive right against the university and the state has several significant advantages. Most importantly, confining the scope of constitutional academic freedom can increase its power within its remaining sphere. It may make more conceptual sense to apply constitutional academic freedom to procedural and structural safeguards than to aprofessional political speech or to intramural speech unrelated to educational concerns. But in all three situations, denying the protection of constitutional academic freedom may provide more popular and judicial support for enforcement of its substantive core. In addition, understandable concerns about judicial intrusions into university life, as in the debate over professional quality, ${ }^{351}$ are assuaged by letting university constituencies themselves work out these procedural and structural issues. ${ }^{352}$ The substantive individual right of academic freedom, as the Supreme Court

349. University of Pennsylvania, $110 \mathrm{~S} \mathrm{Ct}$ at 588.

350. The AAUP brief in Knight was silent on this constitutional issue, though it emphasized as a matter of policy that faculty participation in governance assists the search for truth, a familiar rationale for academic freedom. AAUP's Brief as Amicus Curiae at 2, 4, 11, Minnesola State Board for Community Colleges v Knight, 465 US 271 (1984).

351. See notes $312-25$ and accompanying text.

352. "It is easier for faculty members to fight their board of trustees or administration," Professor Gutmann concludes, "than for them to wrest policy-making authority from their state legislature or the U.S. Supreme Court." Gutmann, Nomos 25: Liberal Democracy at 280-81 (cited in note 193). 
emphasized in Roth and Perry, can still be vindicated in court, even if the absence of constitutionally required additional safeguards within the university makes it harder to do so.

\section{$\mathrm{X}$}

\section{ConCLUSION}

Although the meaning of constitutional academic freedom remains ambiguous, the Supreme Court has clearly recognized it as an unenumerated first amendment right with both individual and institutional components that can be in tension with each other. Individual and institutional academic freedom provide protection for professors and universities against the state. But when a professor asks a court to adjudicate a claim that a university violated his constitutional or contractual academic freedom, the university may respond that judicial resolution of the professor's claim would constitute state intervention in university affairs and thereby infringe the university's own academic freedom.

It makes sense to derive institutional academic freedom from the same value of independent critical inquiry that underlies individual academic freedom, ${ }^{353}$ but it perverts the first amendment and the concept of a bill of rights to subordinate individual academic freedom to broad institutional autonomy from judicial review. I have attempted in this article to suggest clarifications in the constitutional meaning of academic freedom that would enable courts to respect both individual and institutional interests. Individual academic freedom should cover expression within a professor's scholarly expertise and intramural speech on matters of educational policy. Institutional academic freedom should similarly relate to the educational functions of universities, such as the "four essential freedoms" identified by Justice Frankfurter in Sweezy: selection of teachers, students, curriculum, and pedagogy. Independent constitutional rights, such as the free exercise clause and freedom of association, may protect the autonomy of private universities, just as the free speech clause may protect the aprofessional political expressions of faculty. But these additional constitutional rights, because they do not address the distinctive functions of professors and universities, should not fall under the rubric of academic freedom.

Courts are competent to review, without infringing the academic freedom of a university, a professor's claim that a stated academic ground was a pretext for a university decision that violated his academic freedom. Concern about judicial competence and respect for institutional academic freedom, however, should preclude courts from intervening in internal debates between faculty and administrators over the definition of professional quality. Although peer review, procedural safeguards in tenure decisions, and faculty participation in university governance may all promote individual academic freedom, courts should also be reluctant to impose them on universities as first amendment

353. See Gutmann, Democratic Education at 177 (cited in note 193). 
requirements, particularly because doing so might weaken academic freedom at its substantive core. Constitutional academic freedom, despite tensions between its individual and institutional components, can protect universities without sacrificing professors.*

* The Supreme Court decided Rust v Sullivan, 59 USLW 4451 (US May 21, 1991) while this article was in final page proofs. One passage in Chief Justice Rehnquist's majority opinion directly supports my assertion that the traditional functions of public universities require first amendment protection from government attempts to restrict academic speech. See notes 242-46 and accompanying text; see generally Part VIIIB. See also Van Alstyne, 53 L \& Contemp Probs at 109-10 (cited in note 24). After upholding against first amendment challenges government restrictions on discussion about abortion in health care organizations that receive Title $\mathrm{X}$ funds, Rehnquist added:

This is not to suggest that funding by the Government, even when coupled with the freedom of the fund recipients to speak outside the scope of the Government-funded project, is invariably sufficient to justify government control over the content of expression. For example, this Court has recognized that the existence of a Government "subsidy," in the form of Government-owned property, does not justify the restriction of speech in areas that have "been traditionally open to the public for expressive activity," United States $v$. Kokinda, 110 S. Ct. 3115,3119 (1990); Hague v. CIO, 307 U.S. 496, 515 (1989) (opinion of Roberts, J.), or have been "expressly dedicated to speech activity." Kokinda, supra, $10 \mathrm{~S}$. Ct. at 3119; Perry Education Assn. v. Perry Local Educators' Assn., 460 U.S. 37, 45 (1988). Similarly, we have recognized that the university is a traditional sphere of free expression so fundamental to the functioning of our society that the Government's ability to control speech within that sphere by means of conditions attached to the expenditure of Government funds is restricted by the vagueness and overbreadth doctrines of the First Amendment, Keyishian v. Board of Regents, 385 U.S. 589, 603, 605-606 (1967). 59 USLW at 4458. 
